\title{
Simulation of aerosol optical properties over Europe with a 3-D size-resolved aerosol model: comparisons with AERONET data
}

\author{
M. Tombette ${ }^{1}$, P. Chazette ${ }^{2}$, B. Sportisse ${ }^{1}$, and Y. Roustan ${ }^{1}$ \\ ${ }^{1}$ CEREA Joint Laboratory ENPC - EDF R\&D, Université Paris-Est, 77455 Champs sur Marne, France \\ ${ }^{2}$ LSCE, Joint Laboratory CEA-CNRS, 91191 Gif-Sur-Yvette, France
}

Received: 13 November 2007 - Published in Atmos. Chem. Phys. Discuss.: 28 January 2008

Revised: 19 May 2008 - Accepted: 31 October 2008 - Published: 8 December 2008

\begin{abstract}
This paper aims at presenting a model-to-data comparison of the Aerosol Optical Thickness (AOT) and of a few sparse data for Single Scattering Albedo (SSA) over Europe for one year. The main contribution of this paper is the sensitivity study to a large number of parameters, including physical and numerical parameters of the aerosol model itself. The optical parameters are computed from a sizeresolved aerosol model embedded in the POLYPHEMUs system. The methodology is first described, showing that several hypothesis can be made for micro-physical aerosol properties. The simulation is made over one year (2001); statistics and monthly time series for the simulation and AERONET data are used to evaluate the ability of the model to reproduce AOT and vertically averaged SSA fields and their variability. The relation with the uncertainties of measurements is discussed. Then a sensitivity study with respect to the mixing state of the particle, the way to take into account water uptake, numerical parameters and physical parameterizations of the model is carried out. The results indicate that the mixing state of particles has an influence on optical parameters, as well as the computation of the wet diameter. But some physical and numerical parameters associated with the aerosol model itself have even more influence under certain conditions, through the uncertainties on the aerosol chemical composition, and their size distribution.
\end{abstract}

\section{Introduction}

Global warming by greenhouse gases is now well understood and can be assessed. The understanding of the impact of

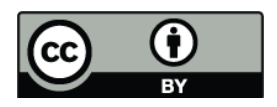

Correspondence to: $\mathrm{M}$. Tombette (tombette@cerea.enpc.fr) aerosols is a much more challenging issue. Aerosol physical processes and direct or indirect effects on the atmosphere are still an open research field and then roughly described in the models. The third and fourth reports of the Intergovernmental Panel on Climate Change (IPCC, Houghton et al., 2001 and Forster et al., 2007) declare that for all these factors, there is no precise estimate of the radiative forcing by anthropogenic aerosols. Current estimates give a cooling of the earth's surface, a warming of the atmosphere, and a negative budget at the top of atmosphere which is estimated to compensate part of the warming due to greenhouse gases. As aerosol direct effects on radiative budget are due to the particles in the whole vertical column, it has been pointed out that the aerosol global models should validate and improve their vertical distribution. To access to this vertical information, comparisons between observed and simulated Aerosol Optical Depth or Thickness (AOD / AOT) have been published for global models compared to satellite measurements or/and ground-based stations measurements (e.g. Chung et al., 2005; Chin et al., 2002; Penner et al., 2002; Kinne et al., 2006; Yu et al., 2006; Ginoux et al., 2006). These models generally use fixed size distributions depending on the aerosol type (sea-salt, sulfate, etc.) in order to compute or tabulate aerosol extinction coefficients.

As the residence time of tropospheric aerosols ranges from 5 to 10 days (Seinfeld and Pandis, 1998), even 1 day in the atmospheric boundary layer, and as the processes governing aerosol physics are complex, it is also interesting to investigate the aerosol vertical distribution at a smaller scale. Regional effects are significant for example on the heating rate of the atmosphere (see INDOEX campaign Ramanathan et al., 2001; Léon et al., 2002). Also, as the key question about climate change deals with the effect due to anthropogenic activities, a special attention has to be paid to sulfate

Published by Copernicus Publications on behalf of the European Geosciences Union. 
that has a cooling impact, and to black carbon (BC) that has a cooling effect on the surface and a heating effect on the boundary layer. For that interest, representation of urban areas is required, and the regional scale is more appropriate. Comparisons between satellite-derived and simulated AOT from Chemistry-Transport Models have also been made (e.g. Robles González et al., 2003; Jeuken et al., 2001; Hodzic et al., 2004; Hodzic et al., 2006). Satellite measurements have the advantage that they provide horizontal information. As the AERONET network accounts for a hundred stations, with a large part in Europe, it is now possible to use it in the same way as the ground-based networks for $\mathrm{PM}_{10}$ have been used for validation. Moreover, AERONET AOT is used to validate AOT retrieved from satellite measurements: MODIS (Kaufman et al., 1997), POLDER (Deuzé et al., 2001), MeteoSat (Brindley and Ignatov, 2006).

Studying the radiative transfer to atmospheric aerosols is also important because of the effect on photochemistry by the modification of the actinic flux in presence of particles (Dickerson et al., 1997; Randriamiarisoa et al., 2004). Moreover, the absorbing or scattering particles change their own properties such as their inner temperature. At microscale, change in the temperature of the particle modifies water condensation (semi-direct effect, Lohmann and Feichter, 2005). This phenomenon also impacts cloud formation, so taking into account the feedback of aerosols on meteorology is also needed.

In this paper, we use a 3-D CTM (Polair3D, Boutahar et al., 2004) coupled with a size-resolved aerosol model (SIREAM, Debry et al., 2007) in the framework of the Poly Phemus system (Mallet et al., 2007). The system has been evaluated for aerosol outputs $\left(\mathrm{PM}_{10}, \mathrm{PM}_{2.5}\right.$ and chemical composition) and gas-phase species at the ground level for year 2001 over Europe (Sartelet et al., 2007) and over Greater Paris (Tombette and Sportisse, 2007). Two optical parameters (AOT and SSA) are computed from the simulation outputs and compared to AERONET data (this is a longterm comparison with several stations).

The objective of this paper is twofold. First, we want to perform a model-to-data comparison for a CTM on the basis of radiative data for a large ground-data basis. Second, a sensitivity study estimates the robustness of the simulated aerosol optical properties.

This paper is organized as follows. Different methods for the computation of AOT are described in Sect. 2. They are based on parameterizations that depend on relative humidity (Hänel, 1976; Gerber, 1985) and that take advantage of the complexity of the model (size distribution and thermodynamics). The relative humidity has a great impact on chemistry and optical parameters of aerosols (Boucher and Anderson, 1995; Randriamiarisoa et al., 2006), which can be poorly described by parameterizations, as the Hänel one that does not take into account the hysteresis effect. Also, the different hypothesis made for the mixing state of the particles are considered. In Sect. 3, we describe the observational network AERONET used for AOT measurements. In Sect. 4, the model configurations for the simulation over Europe are described. Then simulated AOT and SSA in a reference configuration are compared to AERONET data in Sect. 5. A key question is to estimate the uncertainties of the simulated optical parameters. This is discussed in Sect. 6 with the advantages of using such a complex model.

\section{Computation of aerosol optical properties}

\subsection{General equations}

AOT at a wavelength $\lambda$ is defined as the integral of the extinction coefficient $b_{\text {ext }}$ due to particles through the atmosphere:

$\operatorname{AOT}(\lambda)=\int_{z_{g}}^{z_{\mathrm{TOA}}} b_{\text {ext }}(\lambda, z) \mathrm{d} z$

where $z_{\mathrm{TOA}}$ is the altitude at the Top Of Atmosphere and $z_{g}$ the altitude at ground level.

The single scattering albedo used in this study (for comparisons to AERONET data) is computed as the ratio between the aerosol optical thickness due to scattering $\left(\mathrm{AOT}_{\text {scatt }}\right)$ and the total optical thickness. $\mathrm{AOT}_{\text {scatt }}$ is computed in the same way as AOT, from the scattering coefficient.

The extinction coefficient is a function of the particle size, the Aerosol Complex Refractive Index (referred as CRI or ACRI in the following paper) $m$ and the wavelength $\lambda$. For a polydisperse distribution of aerosols with the same ACRI $m$, the Mie theory (Mie, 1908) gives the extinction coefficient by the following formula:

$b_{\text {ext }}=\int_{0}^{D_{\text {wet }}^{\max }} \frac{\pi D_{\text {wet }}^{2}}{4} Q_{\text {ext }}\left(m, \alpha_{\text {wet }}\right) n\left(D_{\text {wet }}\right) \mathrm{d} D_{\text {wet }}$

where $D_{\text {wet }}$ is the wet particle diameter, $D_{\text {wet }}^{\max }$ the maximum wet diameter of the distribution, $\alpha_{\text {wet }}=\frac{\pi D_{\text {wet }}}{\lambda}$ the size parameter, $n\left(D_{\text {wet }}\right)$ the number size distribution function and $Q_{\text {ext }}(m, \alpha)$ the extinction efficiency. The scattering coefficient is computed with the same formula from the scattering efficiency $Q_{\text {scatt }}(m, \alpha)$. The extinction and scattering coefficient are computed through the Mie code of Wiscombe (1980), which is tabulated because of computing costs.

The aerosol model is based on an assumption of internal mixing (aerosols in the same size bin are supposed to have the same chemical composition). The model outputs at one point of the domain are therefore the aerosol composition for each bin and for each vertical level. The AOT computation will be based on the same hypothesis: we consider that in each vertical layer, the aerosol population is divided into $\mathrm{N}_{\text {bin }}$ groups where the discretization of the diameter spectrum is constant (geometric average of the bin bounds). Then, in one bin in one vertical layer, the aerosols have the same optical properties. 


\subsection{Mixing hypothesis}

The ACRI for a particle composed by several species is computed from the CRI of each species. CRI for organic and inorganic species are taken from the OPAC software package (Optical Properties of Aerosols and Clouds, Hess et al., 1998) and interpolated at the desired wavelength. CRI of water is interpolated from Seinfeld and Pandis (1998) (p. 1117). Table 1 gives the correspondence between model and OPAC species. The species with the largest imaginary part of CRI are the major absorbing components of the aerosol. It is then noteworthy that the major absorbing species are BC, dust, nitrate, ammonium and organic species. On the contrary, sulfate and sea-salt are poorly absorbing components.

The computation of ACRI for a particle should be made under an hypothesis on the mixing state of the particle. We propose here two mixing states: the well-mixed case and the core hypothesis.

- Well-mixed hypothesis

The aerosol density is fixed at $\rho_{\text {aerosol }}=1.4 \mathrm{~g} \mathrm{~cm}^{-3}$, as it is assumed in the aerosol model SIREAM. If $\left(c_{s}\right)_{s=1, N s}$ and are $\left(m_{s}\right)_{s=1, N s}$ are the concentrations and the CRI respectively of the $N_{s}$ pure species , the ACRI of a wellmixed particle is:

$m_{\text {mix }}=\frac{\sum_{s=1}^{N s} m_{s} \times c_{s}}{\sum_{s=1}^{N s} c_{s}}$.

As the aerosol density is a constant, Eq. (3) is similar to a volume-averaged ACRI (Seinfeld and Pandis, 1998).

- Core hypothesis

The hypothesis of a well mixed particle is rarely met in real atmospheric conditions, especially for BC. BC cannot be well mixed in the particle because of its geometry and solid state (Katrinak et al., 1993). So BC can be treated as a well-mixed component, as a non-mixed component (core) or as an external component (external mixing). As Jacobson (2000) illustrated, this can influence the absorption cross section for small wavelengths (under $1 \mu \mathrm{m}$ ) and large diameters (over $1 \mu \mathrm{m}$ ). Lesins et al. (2002) show that the mixing scenario significantly influences the imaginary part of ACRI and then the radiative direct forcing estimate (Chung and Seinfeld, 2002). The semi-direct radiative forcing will also be impacted by changes in absorption. We can wonder in this study if these mixing rules influence the computation of optical parameters such as AOT, extinction and absorption and then our results.

In the case of a non-mixed component (core in a solution), we will use the Maxwell-Garnett approximation (Maxwell-Garnett (1904)), which is one of the most widely used methods for calculating the bulk dielectric properties of inhomogeneous materials. Maxwell-
Table 1. Correspondence between PolyphemUs aerosol species and OPAC species. The real (Re) and imaginary parts (Im) of CRI at $\lambda=550 \mathrm{~nm}$ for each species are also given.

\begin{tabular}{llll}
\hline Model Species & OPAC species & Re & Im \\
\hline Nitrate & water soluble & 1.53 & $-6 \times 10^{-3}$ \\
Ammonium & water soluble & 1.53 & $-6 \times 10^{-3}$ \\
Sulfate & sulfate & 1.43 & $-10^{-8}$ \\
Sodium & sea-salt & 1.43 & $-10^{-8}$ \\
Chlorate & sea-salt & 1.43 & $-10^{-8}$ \\
BC & soot & 1.75 & $-4.4 \times 10^{-1}$ \\
Mineral Dust & mineral & 1.53 & $-5.5 \times 10^{-3}$ \\
Primary Organics & insoluble & 1.53 & $-8.0 \times 10^{-3}$ \\
Secondary Organics & insoluble & 1.53 & $-8.0 \times 10^{-3}$ \\
\hline
\end{tabular}

Garnett gives the following expression for the effective dielectric constant:

$\varepsilon_{M G}=\varepsilon_{2}\left[\frac{\varepsilon_{1}+2 \varepsilon_{2}+2 f_{1}\left(\varepsilon_{1}-\varepsilon_{2}\right)}{\varepsilon_{1}+2 \varepsilon_{2}-f_{1}\left(\varepsilon_{1}-\varepsilon_{2}\right.}\right]$

where $\varepsilon_{i}$ are the complex effective dielectric constants (square of ACRI). The subscripts 1 and 2 stand for the inclusion (i.e. core, black carbon in the present study) and solution matrix (i.e. the envelope, all the other components well mixed in this study) respectively. There are three limits of validity for the theory. The first one is that the size of the inclusions should small compared to the wavelength, which is true in our case because $\mathrm{BC}$ exists in the coarse mode in very small quantities as compared to dust for example. The second one is that inclusions should be far one from another (because we neglect the multiple scattering of order greater than 2 ). We consider only one inclusion in our model. The third one is that the volume fraction of the inclusion should be small. Koh (1992) shows that the theory is still a good approximation for volume fractions up to 0.2 , which means that aerosols should have a volume fraction of $\mathrm{BC}$ less than 0.2 , which is true for most of the cases over Europe in an internal mixing approximation (Putaud et al., 2004).

\subsection{RH effect}

The RH effect interferes in the computation of optical parameters through the aerosol wet diameter and the ACRI, which should take the water content into account.

Three ways for computing the wet diameter are implemented:

1. Aerosol Liquid Water Content (ALWC) It is also possible to take aerosol liquid water content as an output of the simulation (computed with the thermodynamic model IsORROPIA Nenes et al., 1998). 
ALWC are then dependent on the chemical composition (but only for inorganic species). The wet diameter is computed from this ALWC (still considering a constant aerosol density) and water is considered as the other species in the computation of the ACRI.

\section{Hänel}

The Hänel formulas (Hänel, 1976) are relations between the wet and dry diameters and the wet and dry ACRI through $R H$. For diameters, we will use the following equation:

$D_{\text {wet }}=D_{\text {dry }} * \exp [-\varepsilon * \ln (1-R H)]$

where $\varepsilon$ ranges from 0.25 for organics to 0.285 for sulfate aerosol. We chose to take $\varepsilon=0.25$ as advised in Chazette and Liousse (2000) and Randriamiarisoa et al. (2006) for urban aerosols.

The wet ACRI $m_{\text {wet }}$ is computed from the dry ACRI $m_{\text {dry }}$, CRI of water $m_{\text {water }}$ and the ratio between the wet and dry diameters:

$m_{\mathrm{wet}}=m_{\mathrm{water}}+\left(m_{\mathrm{dry}}-m_{\mathrm{water}}\right) \times\left(\frac{D_{\mathrm{dry}}}{D_{\mathrm{wet}}}\right)^{3}$

3. Gerber

The Gerber's formula (Gerber, 1985) gives the wet radius $r_{\text {wet }}$ (in $\mathrm{cm}$ ) as a function of the dry radius $r_{\text {dry }}$ (in $\mathrm{cm}$ ), $R H$ and the temperature $T$ (in $\mathrm{K}$ ):

$r_{\text {wet }}=\left[\frac{C_{1}\left(r_{\text {dry }}\right)^{C_{2}}}{C_{3}\left(r_{\text {dry }}\right)^{C_{4}}-\log (R H)}+\left(r_{\text {dry }}\right)^{3}\right]^{\frac{1}{3}}$.

This formula has been written to fit measurements in Gerber (1985), so it may be adapted to particular cases. We have chosen to take the coefficients $\left(C_{i}\right)_{i=1,5}$ such as they fit the dry radii obtained with a thermodynamic module (Sportisse et al., 2006).

\section{Instrumental set up: AERONET data}

AERONET (AErosol RObotic NETwork, Holben et al., 2001) is a network constituted by more than 100 groundbased remote sensing stations providing aerosol optical, microphysical, and radiative measured data. These stations are located world-wide and the network imposes standardization of instruments, calibration, processing and distribution. This provides a basis for model-to-data comparisons at a large scale (here over Europe). It provides for each station, among other data, AOT directly measured by sun photometers and SSA retrieved from direct measurements at different wavelengths $(1020 \mathrm{~nm}, 870 \mathrm{~nm}, 675 \mathrm{~nm}$ and $440 \mathrm{~nm})$. The data are taken from the AERONET website: http://aeronet.gsfc.nasa.gov/. The "level 2.0" data used in this study are cloud-screened and quality-assured. The accuracy on AOT reaches 0.02 (Holben et al., 2001). As given in Dubovik et al. (2000), we set the absolute error on $\mathrm{SSA}$ to $\triangle \mathrm{SSA}(440)=\Delta \operatorname{SSA}(675)=0.03$ if $\mathrm{AOT}(440)>0.3$, $\triangle \operatorname{SSA}(440)=\Delta \operatorname{SSA}(675)=0.07$ otherwise.

For 2001, we found out 19 stations that respect the previous conditions in our domain. The location of the stations taken into account are plotted in Fig. 1. Here we choose to compare the optical data in the mid-visible spectrum with measurements at $550 \mathrm{~nm}$. SSA and AOT at $550 \mathrm{~nm}$ are obtained from the data at 675 and $440 \mathrm{~nm}$ following the Angström law

$X(550)=X(675) \times\left(\frac{550}{675}\right)^{-\alpha}$

where $\alpha$ is the angström exponent given by

$\alpha=\ln \left(\frac{\mathrm{X}(440)}{\mathrm{X}(675)}\right) / \ln \left(\frac{675}{440}\right)$,

where X stands for AOT or SSA. Hamonou et al. (1999) give the relative error for computed data at $550 \mathrm{~nm}$ :

$$
\begin{aligned}
\frac{\Delta X(550)}{X(550)} & =\left(1+\left|\frac{\ln \left(\frac{550}{675}\right)}{\ln \left(\frac{675}{440}\right)}\right|\right) \frac{\Delta X(675)}{X(675)} \\
& +\quad\left|\frac{\ln \left(\frac{550}{675}\right)}{\ln \left(\frac{675}{440}\right)}\right| \frac{\Delta X(440)}{X(440)}
\end{aligned}
$$

Raw data are instantaneous data during daylight, so hourly data are instantaneous data averaged over one hour. As the absolute errors for measurements $\Delta \mathrm{AOT}(440)=\Delta \mathrm{AOT}(675)=0.02$ is given for instantaneous data, the errors for hourly data at $550 \mathrm{~nm}$ are divided by the square root of the number of instantaneous data in one hour.

Simulated data are taken on the same time basis as measurements.

\section{General configuration}

Optical parameters over Europe are computed from outputs of the aerosol model SIREAM, hosted by the ChemistryTransport Model Polair3D. SIREAM is a SIze-REsolved Aerosol Model, described in details in Debry et al. (2007). SIREAM includes 16 aerosol species: 3 primary species (mineral dust, black carbon and primary organic), 5 inorganic species (ammonium, sulfate, nitrate, chlorure and sodium) and 8 organic species solved with the SORGAM model (Schell et al., 2001). In the usual configuration, SIREAM includes 5 bins logarithmically distributed over the size spectrum, that ranges from $0.01 \mu \mathrm{m}$ to $10 \mu \mathrm{m}$. All these models are embedded in the POLYPHEMUS system, available at the web adress http://www.enpc.fr/cerea/polyphemus and which is described in Mallet et al. (2007). 


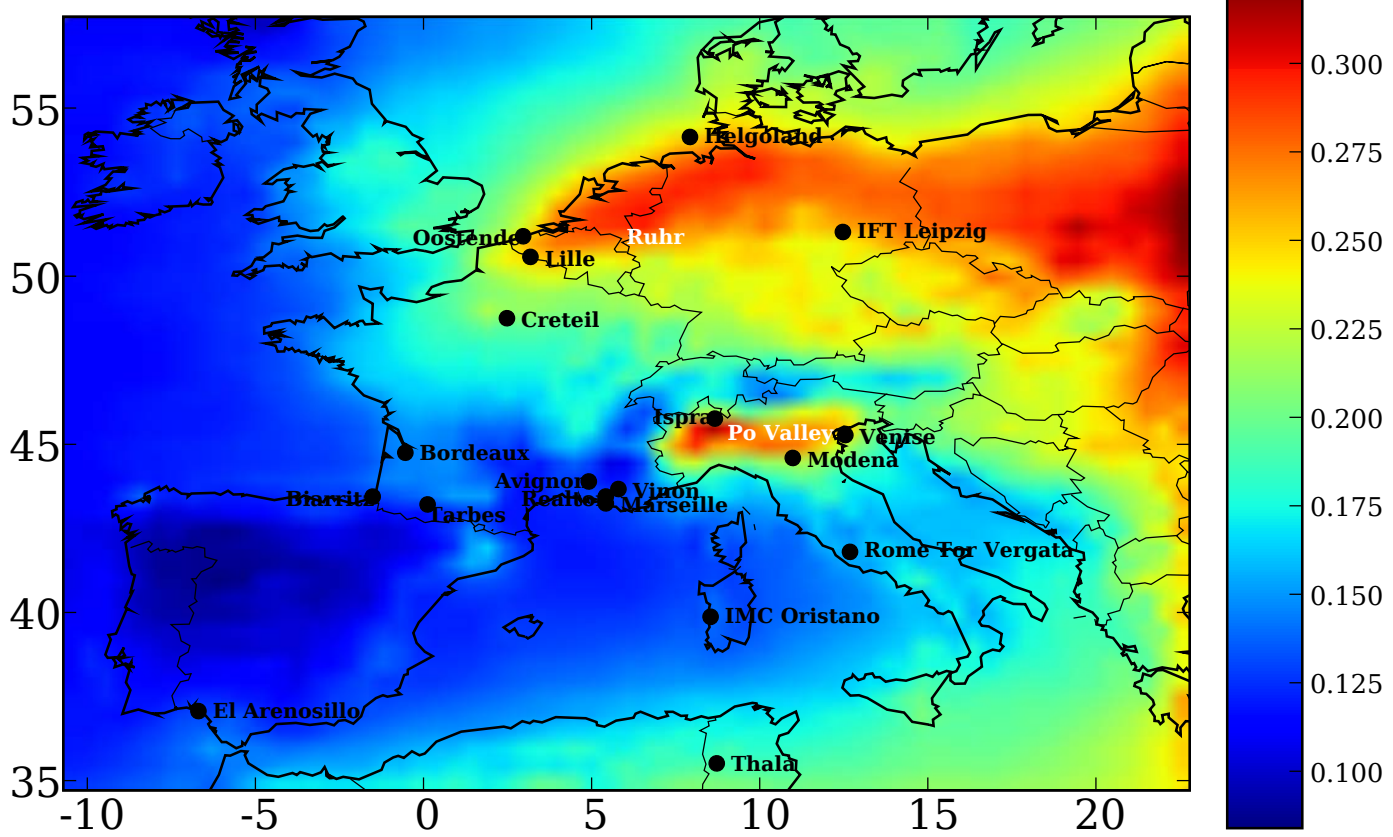

Fig. 1. Average simulated AOT at $550 \mathrm{~nm}$ over year 2001. AERONET stations are drawn.

The simulation at continental scale has the same features as the simulation used for the model validation for $\mathrm{PM}_{10}$ in Sartelet et al. (2007). The main points are quoted hereafter.

The domain covers the area from $10.75^{\circ} \mathrm{W}$ to $22.75^{\circ} \mathrm{E}$ in longitude and from $34.75^{\circ} \mathrm{N}$ to $57.75^{\circ} \mathrm{N}$ in latitude, with a step of $0.5^{\circ}$. Vertically, there are five levels: $0-50 \mathrm{~m}, 50$ $600 \mathrm{~m}, 600-1200 \mathrm{~m}, 1200-2000 \mathrm{~m}$ and $2000-3000 \mathrm{~m}$. The top height of the model is considered as sufficient as a simple calculation gives that $90 \%$ of the aerosol mass is under $3 \mathrm{~km}$ of altitude. This calculation is made by considering that the continental aerosol is constituted by the sum of a remote concentration $c_{r}$ and a continental concentration $c_{c}$, following an exponential decrease with altitude (see Seinfeld and Pandis, 1998, p. 445). The scale heights of those profiles are $1 \mathrm{~km}$ and $8 \mathrm{~km}$ respectively, and typical ground concentrations are taken as $1 \mu \mathrm{g} \mathrm{m}^{-3}$ and $45 \mu \mathrm{g} \mathrm{m}^{-3}$, respectively (Warneck, 1988).

The meteorological fields are interpolated from the operational model of the European Center for Mediumrange Weather Forecast (http://www.ecmwf.int/products/ data/operational_system/), with a resolution of $0.36^{\circ}$ horizontally, 60 sigma-levels vertically and a timestep of $3 \mathrm{~h}$.

The boundary conditions for aerosol species are interpolated from outputs of the GOddard Chemistry Aerosol Radiation and Transport model (GOCART, Chin et al., 2000) for 2001.

The anthropogenic emissions for gases and aerosols are generated from the EMEP expert inventory for 2001 (available at http://www.emep.int).

Chemical species are transported through advection and diffusion. The chemical mechanism used for chemistry is RACM (Regional Atmospheric Chemistry Mechanism, Stockwell et al., 1997). Aerosol and gases are scavenged by dry deposition, rainout and washout. We take into account coagulation and condensation. Nucleation is not solved because the diameters of nucleated particles (typically about $1 \mathrm{~nm}$ ) are lower than the lower diameter bound of the model. Aqueous phase chemistry inside cloud droplets is also described (Variable Size Resolved Model VSRM, Fahey and Pandis, 2001; Strader et al., 1998).

\section{Results and discussion}

We present hereafter comparisons between AERONET and simulated AOT for 2001. The option taken to compute the wet diameter of the particles is the third one (with ALWC). Indeed, ALWC is solved by thermodynamics, it should be the most physical way to compute the wet diameter. $\mathrm{BC}$ is treated as a core in the particle (non well-mixed). The importance of these parameters will be assessed in the sensitivity analysis in Sect. 6.

\subsection{Aerosol Optical Thickness}

Figure 1 shows simulated AOT at $550 \mathrm{~nm}$ over Europe, averaged over the year 2001. Here, we do not take into account mineral dust in the computation of AOT, because the uncertainties about the sources (mainly from Sahara) are too large and because we focus our study on pollution aerosols. Moreover, the annual station based North-Atlantic Oscillation 
Table 2. Definitions of the statistics used in the study. $\left(o_{i}\right)_{i}$ and $\left(c_{i}\right)_{i}$ are the observed and the modeled concentrations at time and location $i$, respectively. $n$ is the number of data.

\begin{tabular}{ll}
\hline Statistic indicator & Definition \\
\hline $\begin{array}{l}\text { Root mean square } \\
\text { error (RMSE) }\end{array}$ & $\sqrt{\frac{1}{n} \sum_{i=1}^{n}\left(c_{i}-o_{i}\right)^{2}}$ \\
Correlation & $\frac{\sum_{i=1}^{n}\left(c_{i}-\bar{c}\right)\left(o_{i}-\bar{o}\right)}{\sqrt{\sum_{i=1}^{n}\left(c_{i}-\bar{c}\right)^{2}} \sqrt{\sum_{i=1}^{n}\left(o_{i}-\bar{o}\right)^{2}}}$ \\
$\begin{array}{l}\text { Mean normalized bias } \\
\text { error (MNBE) }\end{array}$ & $\frac{1}{n} \sum_{i=1}^{n} \frac{c_{i}-o_{i}}{o_{i}}$ \\
$\begin{array}{l}\text { Mean normalized gross } \\
\text { error (MNGE) }\end{array}$ & $\frac{1}{n} \sum_{i=1}^{n} \frac{\left|c_{i}-o_{i}\right|}{o_{i}}$ \\
\hline
\end{tabular}

(NAO) index for year 2001 is equal to $-1.91^{1}$, the transport over the Mediterranean sea from the Sahara to Europe may be weak as described by Moulin et al. (1997). The main regions of high AOT are the Eastern Europe, the Po and the Ruhr valleys. This corresponds to climatological AOT given by global models (Chin et al., 2002; Ginoux et al., 2006), or to annual AOT given in Schaap et al. (2004).

The definition of the statistics used hereafter are quoted in Table 2 . Table 3 presents statistics for hourly data. These results indicate that there is a general good agreement between the simulation and the observations. The differences in the hourly AOT average range from 0.02 for Rome Tor Vergata to 0.07 for Marseille. The correlations range from $40.3 \%$ for Thala (station influenced by dust, that we do not take into account) up to $86.6 \%$ for Biarritz. The RMSE are relatively low, in average in the vicinity of 0.1. MNBEs are negatives for the majority of the stations, which could be attributed to the lack of dust events, dust resuspension or missing description of emission sources.

Equation 10 shows that the relative error of measurements increases with decreasing AOT values. Then, the part of the model-to-observations errors that could be assigned to the uncertainties of measurements depends on the AOT value. To account for those uncertainties, the spectrum of AOT values for observations, ranging from 0 to 1.4 , is divided into 14 classes with an interval of 0.1 . Figure 2 shows the MNGE between the model and the observations (blue bars), the averaged relative errors for measurements (black lines) and the number of available observations for each AOT class. For low AOT values (between 0 and 0.1) that accounts for about $32 \%$ of the data, the model error is entirely included inside the error on measurements. For AOT between 0.1 and 0.2,

\footnotetext{
${ }^{1}$ data published on the web by J.W. Hurrel from the National Center for Atmospheric Research, Boulder, Colorado, USA. See http://www.cgd.ucar.edu/cas/jhurrell/indices.html.
}

Table 3. Number of observations, mean value for mesurements and simulation, RMSE, correlations and NMBE for hourly values of AOT at $550 \mathrm{~nm}$ for simulation. Period: 1 January 2001 to $31 \mathrm{De}-$ cember 2001.

\begin{tabular}{lrllllr}
\hline Station & $\begin{array}{r}\text { \# meas. } \\
\text { (hour) }\end{array}$ & $\begin{array}{l}\text { Meas. } \\
\text { Mean }\end{array}$ & $\begin{array}{l}\text { Sim. } \\
\text { Mean }\end{array}$ & RMSE & $\begin{array}{l}\text { Correl. } \\
(\%)\end{array}$ & $\begin{array}{r}\text { MNBE } \\
(\%)\end{array}$ \\
\hline Avignon & 1875 & 0.15 & 0.11 & 0.10 & $64.7 \%$ & $-17.5 \%$ \\
Bordeaux & 1136 & 0.16 & 0.11 & 0.11 & $67.1 \%$ & $-25.5 \%$ \\
Biarritz & 75 & 0.13 & 0.07 & 0.09 & $86.6 \%$ & $-42.2 \%$ \\
Creteil & 69 & 0.16 & 0.13 & 0.09 & $69.7 \%$ & $14.1 \%$ \\
El Arenosillo & 822 & 0.15 & 0.13 & 0.08 & $65.4 \%$ & $0.7 \%$ \\
Helgoland & 178 & 0.18 & 0.15 & 0.09 & $76.7 \%$ & $-2 \%$ \\
IFT-Leipzig & 594 & 0.23 & 0.17 & 0.15 & $63.3 \%$ & $-9.3 \%$ \\
IMC Oristano & 1901 & 0.16 & 0.13 & 0.08 & $64.7 \%$ & $-7.9 \%$ \\
Ispra & 1730 & 0.21 & 0.19 & 0.16 & $62.3 \%$ & $7.8 \%$ \\
Lille & 441 & 0.20 & 0.17 & 0.09 & $72.1 \%$ & $-7.9 \%$ \\
Marseille & 420 & 0.18 & 0.11 & 0.10 & $82.3 \%$ & $-38.4 \%$ \\
Modena & 83 & 0.21 & 0.15 & 0.14 & $56.9 \%$ & $-2.4 \%$ \\
Oostende & 171 & 0.19 & 0.16 & 0.11 & $81.1 \%$ & $20 \%$ \\
Realtor & 381 & 0.18 & 0.12 & 0.10 & $79.8 \%$ & $-27.3 \%$ \\
Rome Tor Vergata & 1924 & 0.17 & 0.15 & 0.08 & $68.1 \%$ & $1.1 \%$ \\
Thala & 1737 & 0.25 & 0.22 & 0.18 & $40.3 \%$ & $2 \%$ \\
Tarbes & 81 & 0.12 & 0.09 & 0.07 & $78.4 \%$ & $-6.1 \%$ \\
Venice & 1131 & 0.24 & 0.22 & 0.18 & $52.4 \%$ & $26 \%$ \\
Vinon & 402 & 0.15 & 0.11 & 0.07 & $86.2 \%$ & $-25 \%$ \\
\hline
\end{tabular}

that accounts for $35 \%$ of the data, a large part (more than $50 \%$ ) of the error could be attributed to the uncertainties on measurements. For higher AOT values (33\% of the data), the measurements are reliable, so the model only generates the differences. Processes that are not taken into account in the model (the resuspension for example), lack of emission sources, or errors in the transport of species are then the main sources of these discrepencies. These explanations are stressed by the fact that MNBE are negatives for high AOT values with a high MNGE, meaning that in these cases the model underestimates the observations. However, the number of data in the higher AOT classes is too small to conclude for a permanent behaviour of the model.

Figure 3 shows the histogram of the angström exponent (computed from AOT at 440 and $675 \mathrm{~nm}$ ), function of AOT at $550 \mathrm{~nm}$ for the observations. For small AOT values, typically less than 0.4 , where the model error is smaller than or equivalent to the observation error, $\alpha>1.0$ for almost all of the cases. These are pollution cases, and the model reproduces well this pollution. For high AOT values (more than 0.4 ), where the model error could be very large compared to the observation error, some cases where $\alpha>1.0$ present high polluted episodes, but the majority presents dust episodes $(\alpha<1.0)$. For AOT $>0.3,700$ dust cases are listed $(\alpha<1.0)$ versus 150 pollution cases.

Figure 4 shows the comparison of histograms for measurements and simulation for three AERONET stations. Simulation shows good agreement for peaks, even if a slight shift to the left is observed (for each station), which corrobates the model underestimation deduced from Table 3. For Avignon and Rome Tor Vergata stations, the occurences for high AOT 


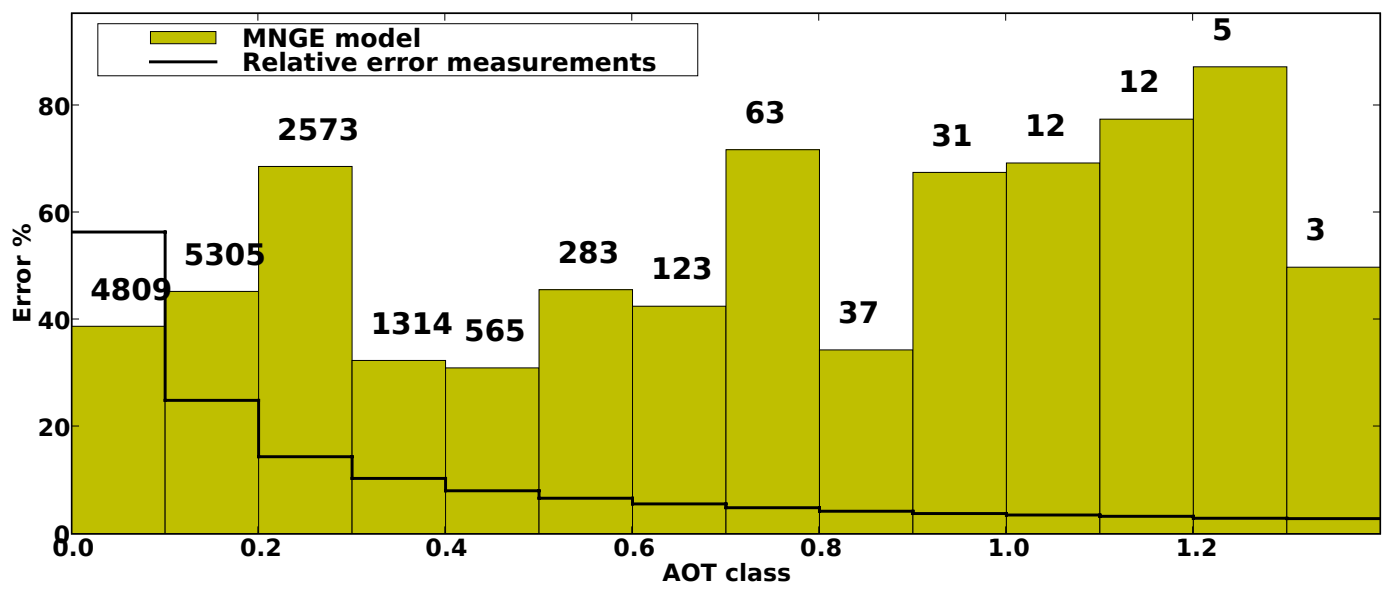

Fig. 2. Model-to-observations MNGE (blue bars) compared to the averaged relative errors for measurements (black lines) for all the AERONET stations considered in this study for 14 observed AOT classes ranging from 0.0 to 1.4 ( 0.1 interval). The number of available observations in each class is mentioned.

values mainly due to pollution aerosols are in good agreement with the data. For Ispra station, the simulation does not represent a few high AOT values that exist on the measurement, probably due to high pollution (or dust) episodes not represented in our model.

Figure 5 presents monthly time series and temporal deviation from the monthly average of AOT for observations (red crosses) and simulations (blue points) for the AERONET stations that present data for more than 5 months. These figures show a general good agreement with observations, often in the range of the observation temporal variability.

These results are comparable to results obtained with other models. For global model, in Chin et al. (2002), AOT is overestimated at low aerosol levels, but simulated AOT agree within a factor of 2 and an overall correlation of $70 \%$ for monthly data and for all considered stations. AOT computed in Ginoux et al. (2006) with global CM2.1 model is overestimated in polluted regions of the nothern Hemisphere by a factor of 2 when compared to AERONET data. For CTMs, Jeuken et al. (2001) find a mean difference between 0.17 and 0.19 and a spatial correlation of $68 \%$ with satellite data over Europe for the month of August 1997. Hodzic et al. (2006) reports a correlation of $61 \%$ for daily AOT at Palaiseau station for summer 2003 and in Hodzic et al. (2004), the RMSE between simulated and observed daily AOT ranges between 0.11 and 0.20 for every scenario considered and for the same station Palaiseau. Comparisons between daily mean AOT at $865 \mathrm{~nm}$ simulations over Europe and data from several AERONET stations in Hodzic et al. (2007) give RMSE ranging from 0.02 to 0.04 , and NMBE of about 20\%. However, these numbers are given for a small period of time (15 days in August 2003).

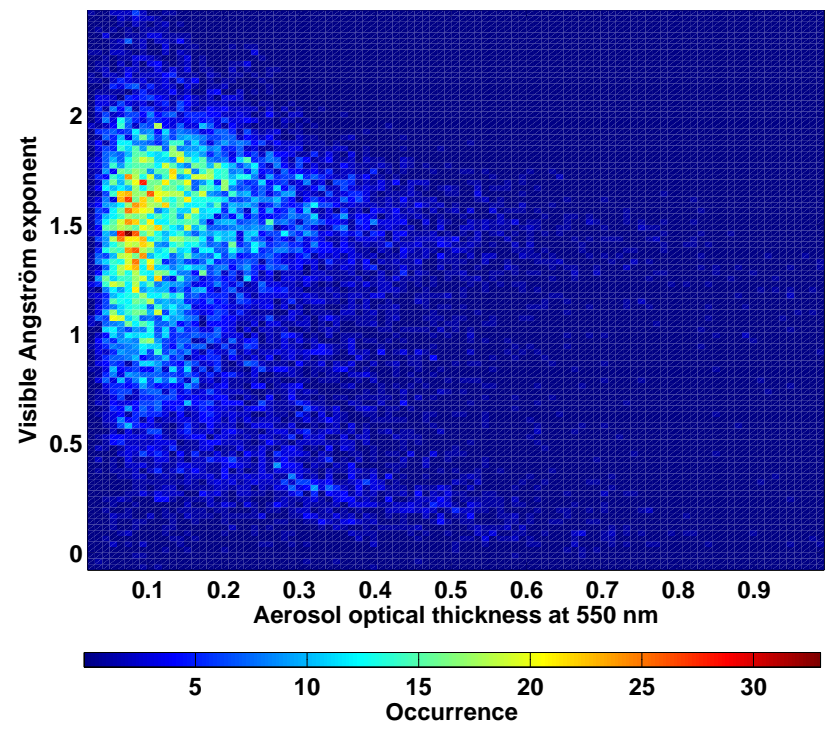

Fig. 3. Histograms showing the angström exponent computed from AOT at 440 and $675 \mathrm{~nm}$, function of AOT at $550 \mathrm{~nm}$ for the observations.

\subsection{Single Scattering Albedo}

SSA, averaged over 2001, is shown in Fig. 6. SSA ranges from 0.90 to 0.96 . The averaged value over the domain is approximately 0.93 . Lower values are observed over cities, as observed usually in high polluted areas $(0.81$ for Bergin et al., 2001 over Beijing, 0.8-0.88 over Mexico City for Baumgardner et al., 2000). The very low values near the eastern boundary of the domain is due to differences in $\mathrm{BC}$ concentrations between the boundary conditions and the concentrations computed by the model from the emission inventory. In Paris, simulated SSA for our study lies in the range 0.88- 

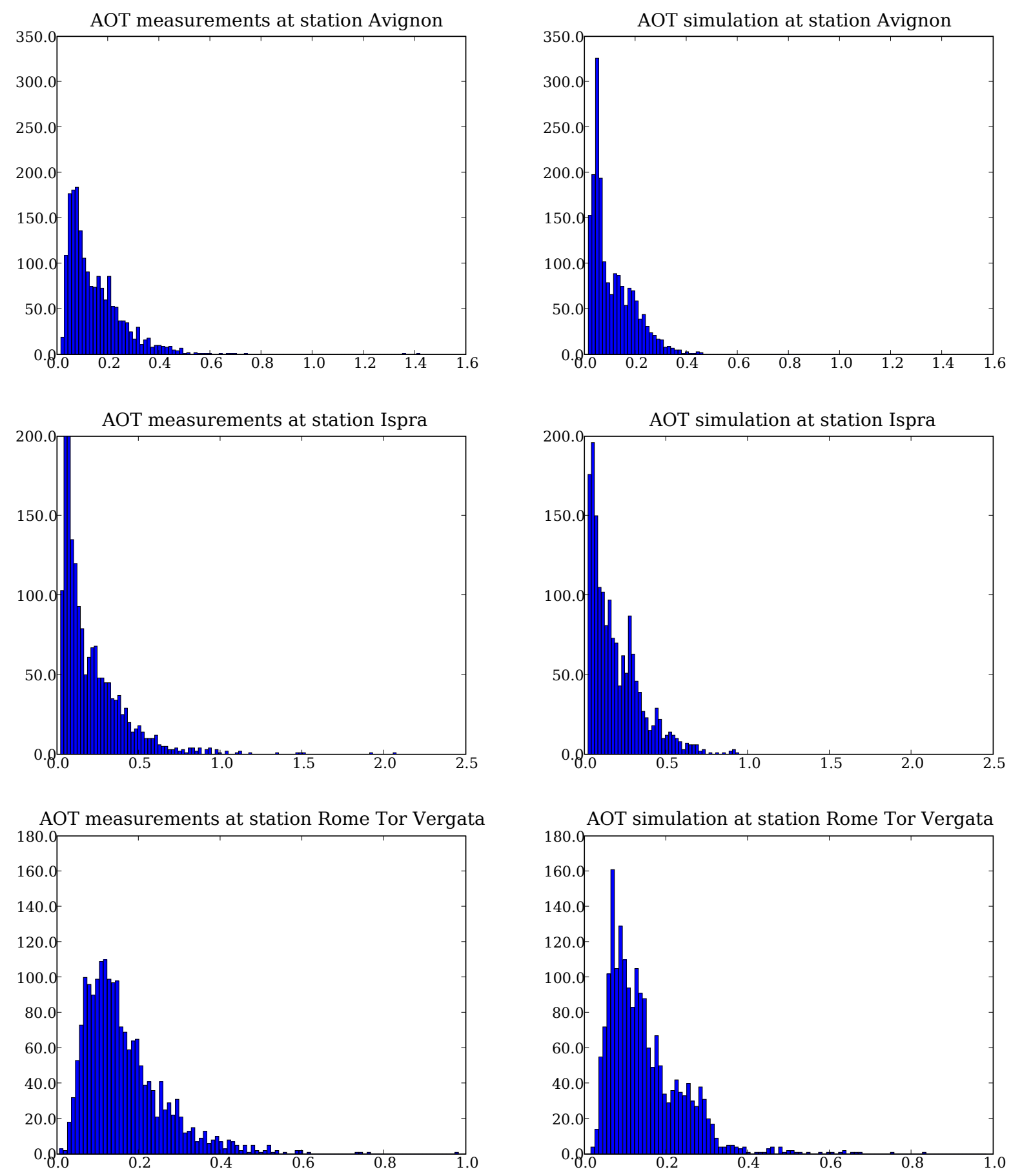

Fig. 4. AOT histograms for AERONET measurements (left) and simulation (right) at stations Avignon (up), Ispra (midle) and Rome Tor Vergata (down).

0.90, which is coherent with the values obtained for the ESQUIF experiment (Raut and Chazette, 2007b; Chazette et al., 2005). In the southeastern part of France, simulated SSA ranges here from 0.91 to 0.93 , that is in the range $0.85 \pm 0.5$ found in Mallet et al. (2003). These low values for SSA over cities indicate that aerosols are more absorbing, certainly due to the high concentrations of soot from transport emissions. As the heating rate of the atmosphere is proportional 

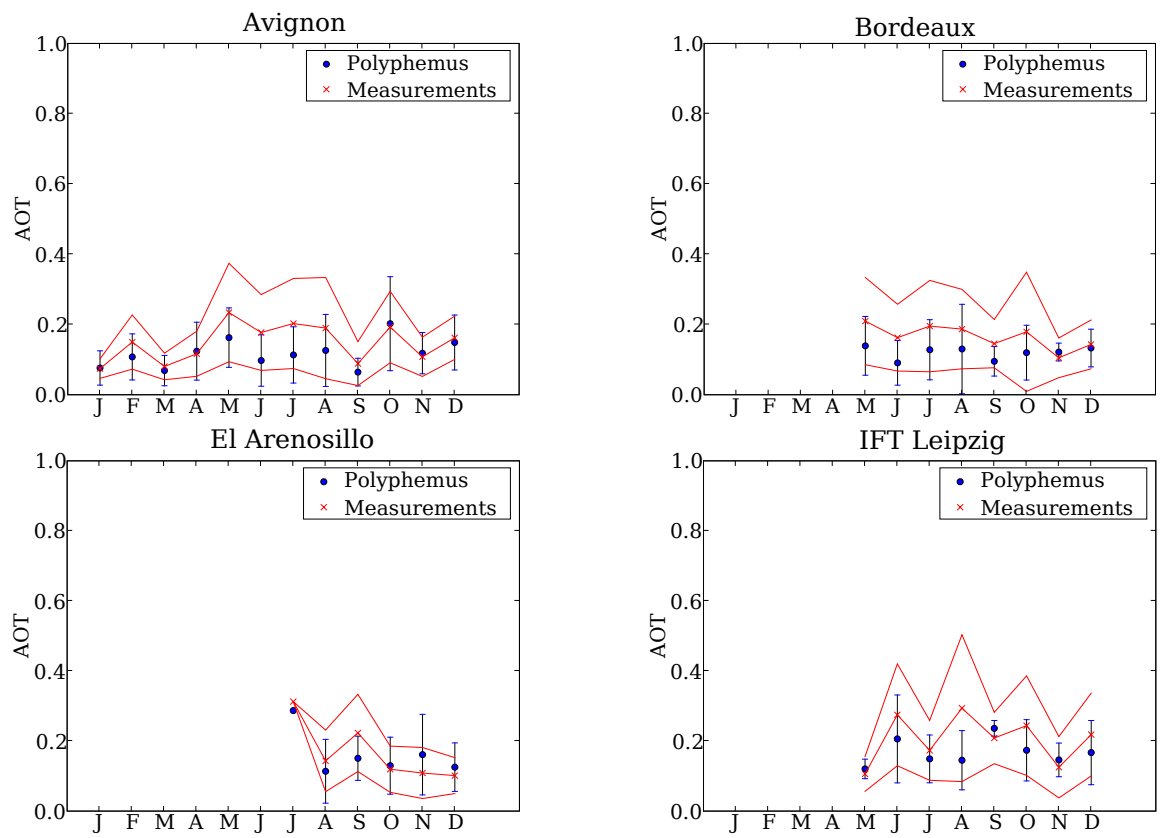

IMC Oristano
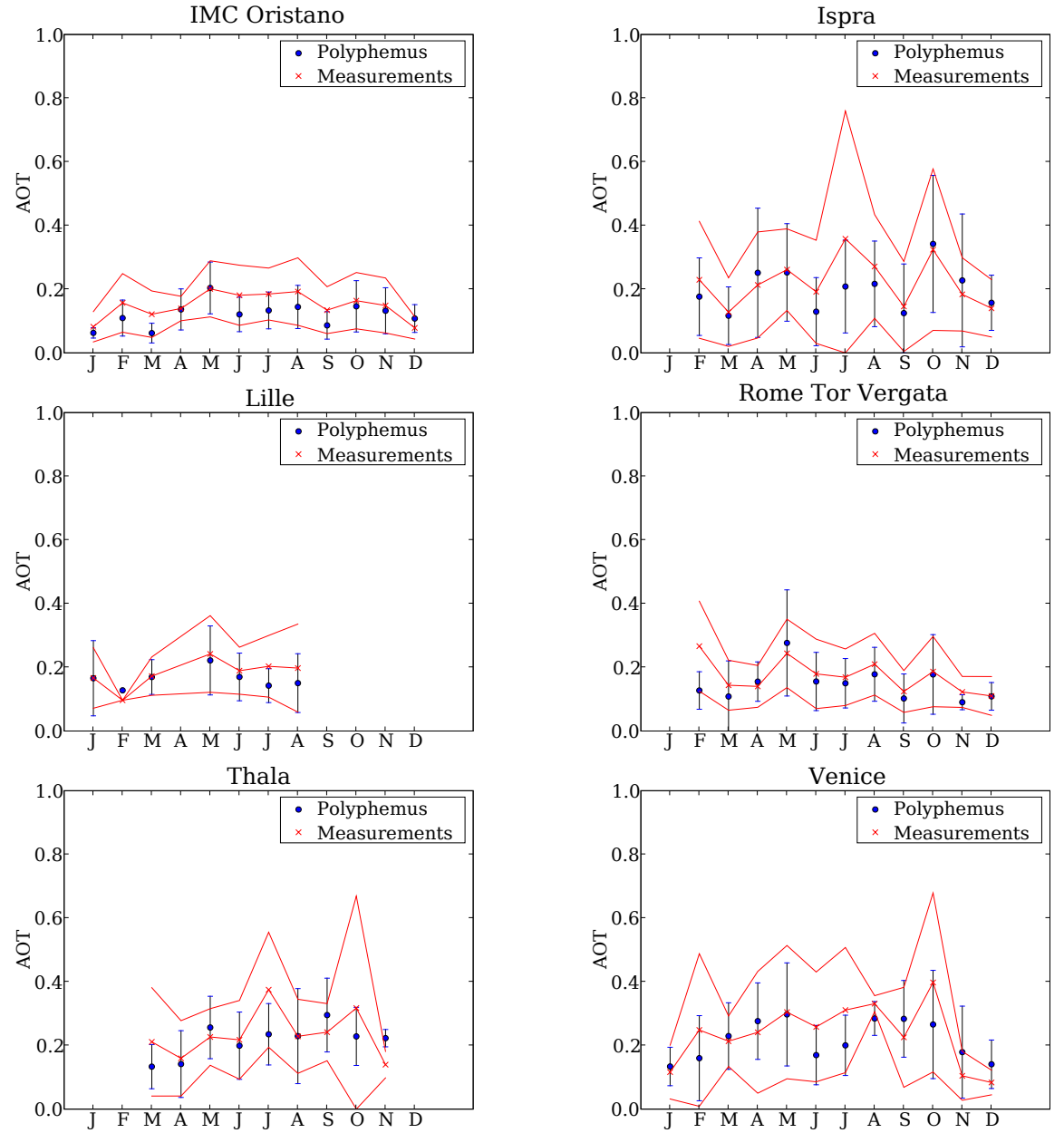

Fig. 5. Comparison between monthly averaged AOT at $550 \mathrm{~nm}$ for AERONET data (red crosses), and simulated (blue points). Observations are comprised between two red curves, defining the range $\overline{\text { obs }} \pm \sigma$ (obs). The model variability is represented by error bars indicating $\overline{\text { model }} \pm \sigma$ (model). Here, $\sigma$ is the temporal deviation for the observations and the model. 


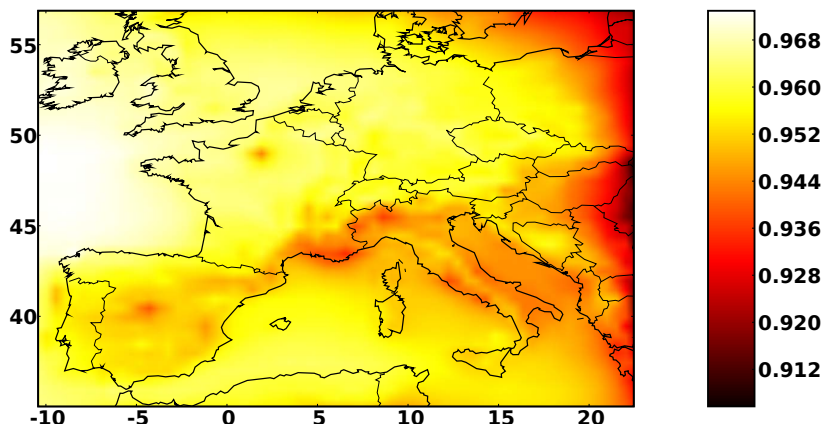

Fig. 6. Average of simulated SSA at $550 \mathrm{~nm}$ over year 2001.

to (1-SSA), this shows that industrial and urban regions are heated due to anthropogenic aerosols.

Table 4 shows the average of SSA retrieved from AERONET measurements and the averaged simulated SSA at the same stations and the same time. The data for SSA are too few to make further statistics, but the simulated SSA lie in the range of observations. Figure 7 shows the time series of simulated SSA (blue line) and measurements (red points) with the error associated to measurements computed as described in Sect. 3 (black lines) for year 2001 at Ispra station. Simulation shows SSA relatively close to the observations, except for a small period in May and a majority of measurements in November where the model seems to miss events for which absorbing elements dominate the aerosol chemical composition. In spring at Ispra station, there could be more well-mixed particles that are more absorbing (Kaskaoutis et al., 2007), whereas the model considers here a core of soot for the calculation of optical properties.

\section{Discussion and sensitivity study of aerosol optical properties}

We present hereafter an investigation of the sensitivity of AOT and of SSA with respect to the mixing state of the particle, the way to compute the wet diameter, some physical parameterizations and the numerical resolution of the aerosol model. The impact of the changes will be quantify with the RMSE and the MNGE (sometimes the MNBE will be specified) between the fields of the reference and of the test over the whole domain. The same formulas of Table 2 are used, with $o_{i}$ the concentrations of the reference simulation and $s_{i}$ the concentrations for the test case. It is not properly an error anymore, but we will keep the acronym for homogenization concern.

\subsection{Description of the sensitivity tests}

The configuration of the so-called reference simulation is identical to the one described in Sect. 4. For computational burden reason, the sensitivity tests will be done over a period
Table 4. Number of observations, mean value for mesurements and simulation, for hourly values of SSA at $550 \mathrm{~nm}$. RMSE, correlations and NMBE are not computed because of the lack of data. Period: 2001-01-01 to 2001-12-31.

\begin{tabular}{lrrr}
\hline Station & \# meas. (day) & Meas. Mean & Sim. Mean \\
\hline Avignon & 16 & 0.93 & 0.94 \\
Bordeaux & 24 & 0.92 & 0.94 \\
El Arenosillo & 13 & 0.91 & 0.95 \\
IMC Oristano & 20 & 0.93 & 0.94 \\
Ispra & 74 & 0.92 & 0.94 \\
Lille & 18 & 0.92 & 0.94 \\
Marseille & 6 & 0.92 & 0.94 \\
Oostende & 9 & 0.89 & 0.95 \\
Realtor & 7 & 0.96 & 0.94 \\
Thala & 66 & 0.90 & 0.95 \\
Venice & 32 & 0.96 & 0.94 \\
\hline
\end{tabular}

of two months. To account for a large number of meteorological situations, two periods are extracted: a summer period from 15 July to 14 August and a winter period from 15 November to 14 December.

The sensitivity tests that concern the aerosol model are done as in Mallet and Sportisse (2006): each simulation has only one parameter or parameterization different from the reference ("One Factor at a Time") and is called the "alternative". Concerning the optical model, the mixing state of the particle and the way to compute the wet diameter will also be tested.

Table 5 summarizes the different tests carried out in this study. Hereafter is a more detailed description of each tested parameter.

The first three tests aim at testing the different possibilities for the computation of the optical properties presented in Sect. 2. Test 1 deals with the mixing state hypothesis: in the reference simulation the $\mathrm{BC}$ is considered as a core, whereas in the alternative the particle is supposed to be well mixed. Test 2 also considers a well-mixed particle, but the wet diameter is computed with the Gerber's formula. In Test 3, the particle is also considered well-mixed, the wet diameter and the wet ACRI are computed with the Hänel's formulas.

The computation of the vertical diffusion coefficient $K_{z}$ is done with the Troen-Mahrt parameterization (Troen and Mahrt, 1986) in the reference simulation. The Louis' parameterization (Louis, 1979) is used instead in Test 4.

The sea-salt particles generation is computed with the Monahan's parameterization (Monahan et al., 1986) in the reference simulation. This parameterization takes only into account the indirect mechanism for sea-salt generation (bubbles bursting). Test 5 will use the Smith's parameterization (Smith and Harrison, 1998) which also takes the indirect mechanism into account (spume). The differences in sea-salt emissions could be up to $20 \%$ in total mass (calculation over year 2001). 


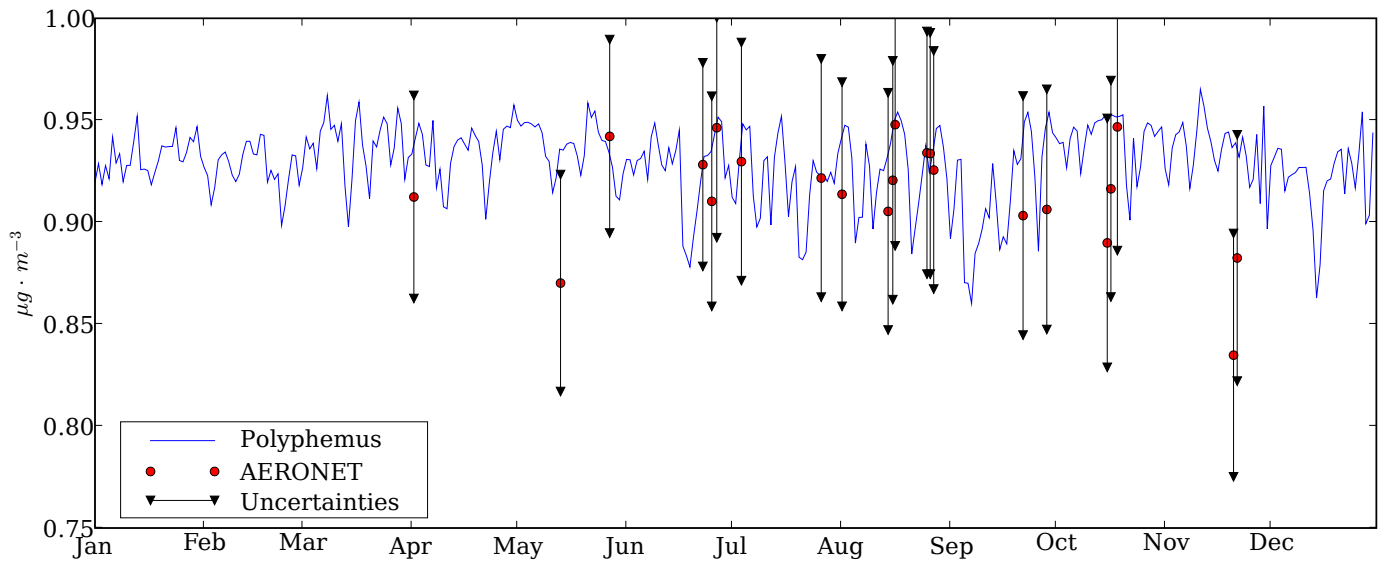

Fig. 7. Comparison between hourly SSA at $550 \mathrm{~nm}$ for AERONET data (red points), and simulated (blue line) at Ispra station. The uncertainties in measurements are represented (black line delimited by triangles).

Table 5. List of the tests for the sensitivity analysis.

\begin{tabular}{lllll}
\hline Test Nr. & Parameter & Reference & Alternative & Altern. name \\
\hline 1 & Mixing state & BC core & Well-mixed & Well-mixed \\
2 & Computation of wet diameter & ALWC + BC core & Gerber + Well-mixed & gerber \\
3 & + Mixing state & & Hänel + Well-mixed & hanel \\
4 & Sea-salt generation & Monahan & Smith & sea-salt \\
5 & $K_{z}$ Coefficient & Troen-Mahrt & Louis & Kz-Louis \\
6 & c/e resolution & Full equilibrium & Hybrid with & hybrid-3 \\
& & & 3 sections at equilibrium & \\
7 & & & Fully dynamic & dynamic \\
8 & Sea-salt for c/e & not taken into account & taken into account & iso-nacl \\
9 & Start threshold & LWC $\leq 0.05 \mathrm{~g} \mathrm{~m}^{3}$ & cloud fraction $\geq 20 \%$ & cloud-20pc \\
10 & Heterogeneous reactions & All & All except & RH-N2O5 \\
& & & the one implying $\mathrm{N}_{2} \mathrm{O}_{5}$ & \\
11 & Section number & 5 & 10 & 10 -sections \\
12 & Vertical level number & 5 & 10 & $10-$ levels \\
13 & Minimum diameter & $d_{\min }=0.01 \mu \mathrm{m}$ & $d_{\text {min }}=0.001 \mu \mathrm{m}$ & nucleation \\
\end{tabular}

The resolution of condensation/evaporation is an important factor for the aerosol model. The equilibrium hypothesis between gases and aerosols seems to be justified for small particles (Pilinis et al., 2000; Debry and Sportisse, 2006). A dynamical resolution, even if it is computationally requiring, may be necessary for coarse particles for which the mass transfer between gas and aerosol phases could be slower. It is possible to choose to solve all the model sections with the equilibrium hypothesis (reference simulation), or to solve all the sections dynamically (as it is done in Test 7). An alternative simulation will test an hybrid method (Test 6), where only the two sections of largest diameters will be solved dynamically, and the other three sections will be solved at equilibrium. The cutting diameter is then approximately $0.6 \mu \mathrm{m}$.

In the reference simulation, the sea-salt species ( $\mathrm{Na}$ and $\mathrm{Cl}$ ) are not taken into account for the computation of the ther- modynamic equilibria of inorganic species with ISORROPIA, then they do not influence the equilibrium of ammonium, sulfate and nitrate. This choice has been made on the basis of comparisons to measurements, and on the argument that the sea-salt aerosols could be found in atmospheric conditions in an external mixing state with the other particles in the vicinity of the emission sources where their concentrations are important. Test 8 will take into account the sea-salt for the thermodynamic equilibria.

The aqueous chemistry has a large impact on sulfate concentrations. In presence of clouds, reactions producing sulfate (essentially) are catalyzed. The uncertainties due to the aqueous chemistry could, in addition to the uncertainties due to the model itself, be due to the meteorological data or to the way to interpret them. The aqueous chemistry is activated when a cloud is detected. Either a threshold 


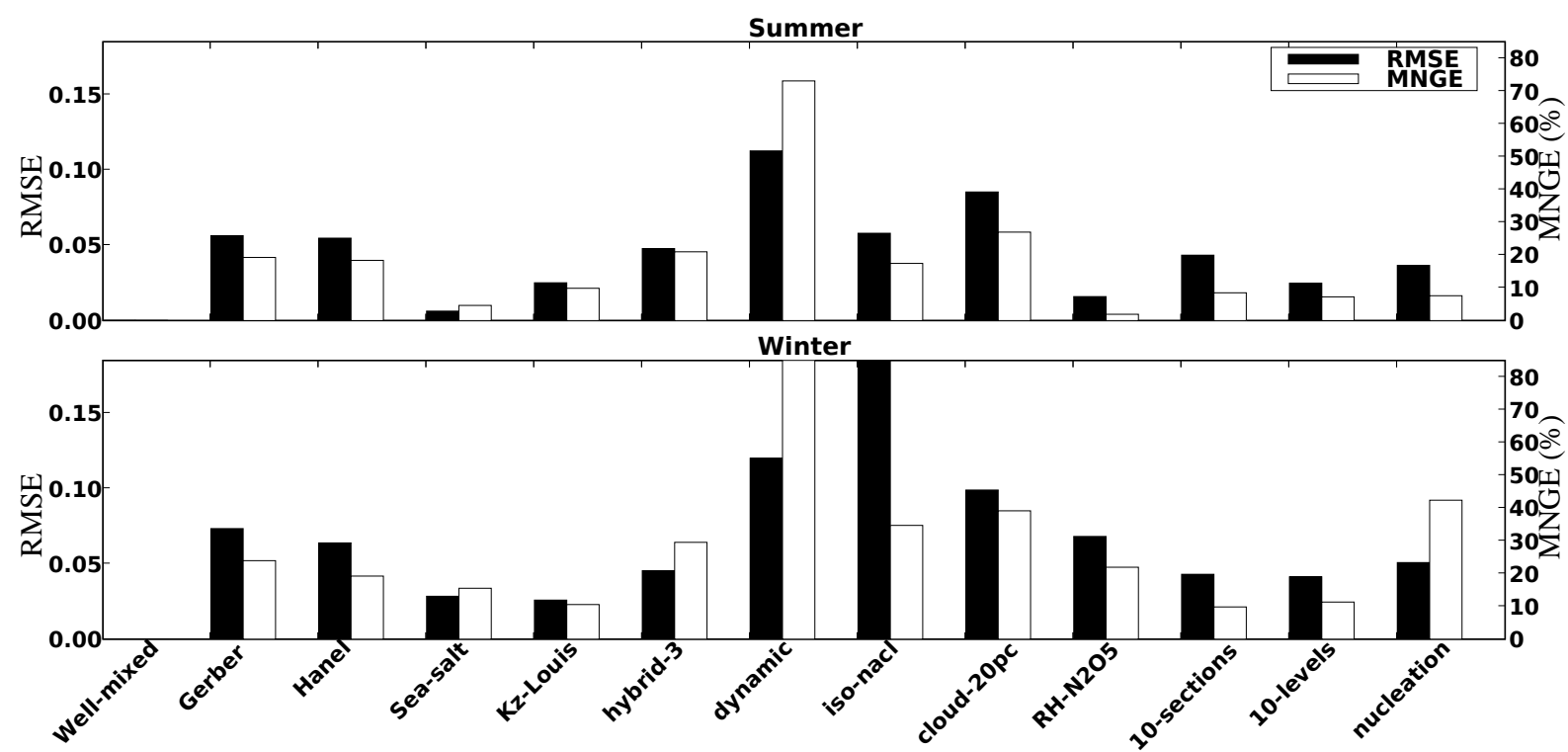

Fig. 8. RMSE (black) and MNGE (white) in winter and in summer between the reference and each alternative simulation for AOT at $550 \mathrm{~nm}$.

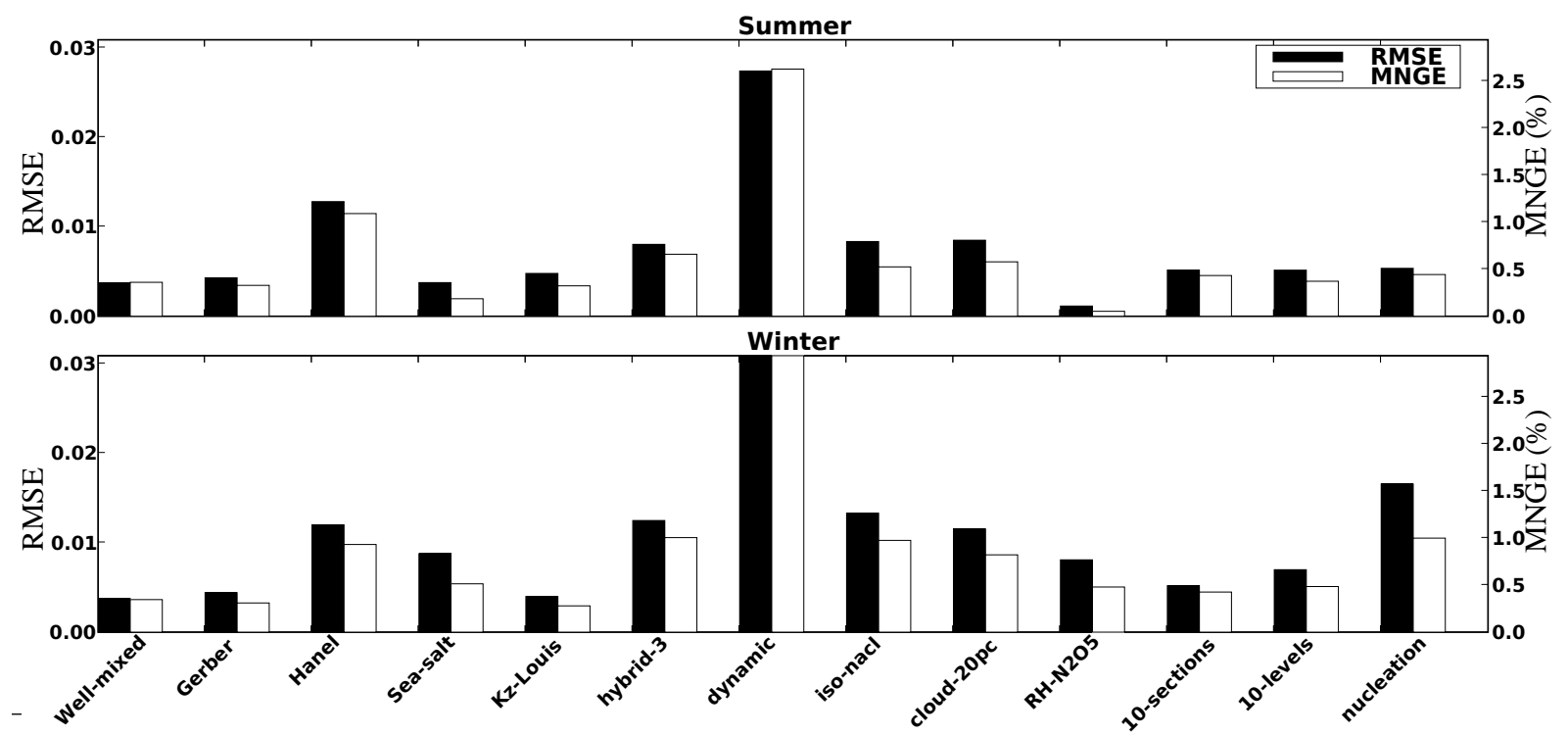

Fig. 9. RMSE (black) and MNGE (white) in winter and in summer between the reference and each alternative simulation for SSA at $550 \mathrm{~nm}$.

on the Liquid Water Content (LWC) or on the cloud fraction (CMAQ, 1999) in the cell could be used to detect a cloud. In the reference simulation, a maximum threshold of $0.07 \mathrm{~g} \mathrm{~m}^{-3}$ on the LWC is used. In Test 9 , the aqueous chemistry is called when the cloud fraction exceeds $20 \%$.

An other source of uncertainties in the model is connected to the heterogeneous reactions in the gas-phase, which take place on the aerosol surface (Jacob, 2000). These reactions produce $\mathrm{HNO}_{3}$, that condense on aerosol as nitrate. In conclusion of tests not shown here, the reaction involving the $\mathrm{N}_{2} \mathrm{O}_{5}$ reveals to be the most important. The reference simulation takes these reactions into account, with the reaction probabilities taken as the minimum of the recommended values in Jacob (2000). Test 10 will switch off the reaction involving $\mathrm{N}_{2} \mathrm{O}_{5}$.

The discretization of the aerosol size spectrum interferes in the redistribution process after condensation. It is also an important parameter in the computation of the extinction coefficient. Given the number of order of magnitude between the smallest diameter $(0.01 \mu \mathrm{m})$ and the largest $(10 \mu \mathrm{m})$ of the spectrum, the discretization should not be too coarse unless numerical diffusion could be generated. This is also a 
critical parameter in regard of computational costs. The reference simulation considers 5 size sections and Test 11 will consider 10 sections, logarithmically distributed.

The aerosol vertical distribution will highly depend on turbulence. This phenomenon happens at a small scale, so the vertical discretization could influence the results. The reference simulation presents 5 vertical levels. Test 12 will present 10 levels, with a top altitude unchanged at $3000 \mathrm{~m}$ height, where the added levels are essentially in the planetary boundary layer.

Nucleation is often not solved at a meso-scale, because it has a little impact on total mass. Moreover, in the reference configuration of the model, the minimum diameter is $0.01 \mu \mathrm{m}$ whereas nucleated particles have a typical diameter of $0.001 \mu \mathrm{m}$. Test 13 solves the nucleation, and with the lowest bound for the size spectrum fixed to $0.001 \mu \mathrm{m}$ (two sections are added).

\subsection{Results and discussion}

\subsubsection{General remarks}

Figures 8 and 9 show the impact of the different configurations respectively on the computation of AOT and SSA at $550 \mathrm{~nm}$, quantitatively through the RMSE and the MNGE of each alternative versus the reference simulation. The RMSEs for the tests dealing with the aerosol model (Tests 4-13) is in the range [0.06-0.18] for AOT and in the range [0.004-0.03] for SSA. The MNGEs are in the range [2\%-85\%] for AOT and in the range $[0.05 \%-3 \%]$ for SSA.

It is noteworthy that the RMSEs on AOT obtained by the sensitivity tests are comparable to the RMSEs found in comparison to observations. The MNGE could be as large as $80 \%$ (for the "dynamic" simulation in winter). This remark is also true for SSA, the RMSE is about 0.01 in average over all sensitivity tests, which is in the same range as the differences between the simulated and observed mean for SSA shown in Table 4 . The MNGE is about $1 \%$ in average, which means a larger difference on the absorption coefficient.

The first remark is that the tests that deal with the computation of the optical parameters (mixing state and RH effect) result in an equivalent sensitivity to the tests on the aerosol model itself. Moreover, the simulations that give the largest differences concern the condensation/evaporation process ("dynamic" or "iso-nacl" for example). The test about the mixing state of the aerosols presents almost no differences on AOT with the reference configuration where BC is considered as a core (less than $10^{-4}$ for the RMSE). The hypothesis on the mixing state of the particle has an importance on SSA (about 0.004 for the RMSE and about $0.4 \%$ for the MNGE), and then on the absorption process. But the differences on SSA obtained with this simulation are smaller than differences obtained by the other tests on the aerosol model. The differences for AOT obtained by the tests on the RH effect ("Gerber" and "Hanel") are non-negligible (about
0.06 for the RMSE and 20\% for the MNGE). As the "Wellmixed" test gives no difference, the impact on AOT in these cases is only due to the computation of the wet diameter. The impact of the "Hanel" simulation on SSA ( 0.01 for the RMSE and about $1 \%$ for the MNGE) is more important than the impact of the "well-mixed" and the "Gerber" simulations (about 0.004 for the RMSE and $0.4 \%$ for the MNGE). As the main difference between the "Gerber" and the "Hanel" simulations is the computation of the ACRI (from ALWC for "Gerber" and from Hänel's formula for "Hanel"), this result shows that the parameterization of the RH effect has a nonnegligible impact on the absorption coefficient.

\subsubsection{Tests with an impact on the vertical profile}

The simulations "Kz-Louis" and "10-levels" influence the vertical profile of aerosols. The impact on aerosol primary species is relatively large (for example, the MNGE is about $15 \%$ for BC concentrations). But the influence of these simulation on SSA is quite weak in comparison with some other tests (less than $0.5 \%$ for the MNGE). This means that the vertical sum in the computation of the optical parameters tends to compensate part of the differences.

\subsubsection{Tests on the condensation process}

For AOT, the "dynamic" simulation is the one that has the highest RMSE (0.12) and the highest MNGE (70\%) in summer. It presents the highest MNGE (82\%) and the second highest RMSE (0.13) in winter. The other simulation which deals with the resolution of condensation also has an important impact, mainly in winter as expected: "hybrid-3" has a RMSE of 0.05 and a MNGE in the range 20-30\%. These simulations highly decrease the mean AOT over the domain for both periods: 0.1 for "dynamic" and 0.14 for "hybrid-3" in summer ( 0.17 for the reference), 0.09 for "dynamic" and 0.13 for "hybrid-3" in winter ( 0.17 for the reference). The SSA is also very sensitive to these simulations, with a RMSE in the range 0.008-0.13 and a MNGE in the range 0.6-1.1 for the "dynamic" simulation. The mean SSA is decreased for the same simulation: the SSA value is 0.92 in summer, whereas it is 0.95 for the reference simulation. The $\mathrm{PM}_{10}$ concentrations for this simulation are lower than for the reference (MNBE of $-5 \%$ in winter and $-4 \%$ in summer), which explains the weak values for AOT. Moreover, this simulation presents a shift of the mass to the large diameters, that decreases the total number of particles.

In winter, the "iso-nacl" simulation presents the largest RMSE (0.18) and a MNGE of 34\%. In summer, this simulation has an influence more equivalent to the influence of other simulations, with 0.06 for the RMSE and $20 \%$ for the MNGE. The value of AOT is also highly increased, its value is 0.20 in summer ( 0.17 for the reference) and 0.28 in winter ( 0.17 for the reference). The SSA is also sensitive, with a RMSE in the range 0.009 in summer and 0.013 in winter, 
and a MNGE value in the range $0.5-1 \%$. The $\mathrm{PM}_{10}$ concentrations are higher in winter (NMBE of 23\%) and in summer ( $6 \%$ for the MNBE). The mass is increased mainly in the fine mode, due to the redistribution of chlore and sodium after equilibrium, which corresponds to an increase of AOT. It is noteworthy that this simulation decreases the chlore concentrations (NMBE of $-67 \%$ in summer and of $-33 \%$ in winter) to the benefit of the nitrate concentrations (MNBE of $167 \%$ in summer and $461 \%$ in winter). The imaginary part of the ACRI is increased, the aerosol is then more absorbing. The SSA should be smaller than for the reference, but it is not the case (the mean SSA is 0.95 ). This could indicate that in this case the differences on the imaginary part of the ACRI are less important for optical properties than the changes in the size distribution.

\subsubsection{Test on the number of sections}

The "10-sections" simulation should influence the mass repartition along the aerosol size spectrum, but the influence on AOT is less important than other tests (RMSE of 0.05 and NMGE of $12 \%$ ). The $\mathrm{PM}_{10}$ concentrations for this simulation have a low bias (MNBE of $-3.2 \%$ in winter and $-0.4 \%$ in summer), and the size distribution is not changed enough to influence the extinction and absorption efficiencies.

\subsubsection{Test with an impact on the chemical composition}

The simulation that spatially modifies the computation of aqueous chemistry ("cloud-20pc") also have an important impact, mainly in winter (RMSE of 0.8 and MNGE of 20$30 \%$ for AOT). This simulation has an important impact on the concentrations of all the inorganic species through the thermodynamic equilibria (the MNGE is $17 \%$ for sulfate, $74 \%$ for nitrate and $13 \%$ for ammonium). This shows that the uncertainties on the aerosol composition is also a key parameter to compute the optical properties. One has to add the uncertainties on the organic part of the aerosol, which is known to be underpredicted in actual models and for which the ACRI is also uncertain. The influence of the aerosol composition is also the main origin for the large influence of the "RH-N2O5" in winter (which increases the nitrate concentrations mainly in winter when condensation occurs). The impact of this simulation on AOT (RMSE of 0.07 and MNGE of $20 \%$ in winter) is even more important than the impact of the computation of the wet diameter. The "sea-salt" simulation has mainly an impact on SSA computation (RMSE of 0.05 and MNGE of $0.5 \%$ ) in winter (where the parameterizations give important sea-salt concentrations due to high wind speed). This is due to the fact that adding sodium and chlore decreases the imaginary part of the ACRI and then the absorption.

\subsubsection{Nucleation}

At last, the nucleation also has a great importance, especially in winter, on AOT (RMSE of 0.06 and MNGE of 40\%) as well as on SSA (RMSE of 0.017 and MNGE of 1\%). The AOT is increased to 0.18 in summer and decreased to 0.14 in winter. The nucleated particles are often neglected by the model at a continental scale because the main target is the total mass $\left(\mathrm{PM}_{10}\right.$ or $\left.\mathrm{PM}_{2.5}\right)$. But these results indicate that this process has to be taken into account when the radiative parameters are the interest.

\subsection{Comparison of the ensemble to the observations}

We consider the ensemble constituted by the 14 different simulations presented above (taking into acount the reference simulation). The previous section discussed about model-tomodel comparisons. The ensemble is now compared to the AERONET measurements, to show that all the considered parameterizations are realistic.

Above all simulations, the RMSE for AOT, averaged over all stations is in the range [0.07-0.18] in winter and [0.100.17 ] in summer. The correlations are in the range [22-69\%] in winter and [59-77\%] in summer. The best simulations, in the sense where the RMSE is the lowest, are the "iso-nacl" in summer and the "hybrid-3" in winter. In winter, the "isonacl" simulation is the worst. It seems then not optimal to choose one configuration instead of another, because it is the best, in the sense of the RMSE is the lowest, for one case. Ensemble methods could then be powerful tools to improve the computation of radiative parameters because it considers model combination.

The sparsity, in space and time, of the data used in this study does not allow us to investigate such methods in our case. Moreover, the ensemble of simulations could be improved: in november, approximately $60 \%$ of the observations are in the envelope formed by all simulations, whereas in july there is only $36 \%$ in the envelope and $62 \%$ above.

\section{Conclusion and perspectives}

We described different methods to compute the aerosol optical properties from outputs of a size-resolved model. Comparisons between simulated AOT from a complex 3-D sizeresolved aerosol model and AERONET data have shown good agreement, when taking into account the aerosol water content computed from the inorganics composition, and with the hypothesis that $\mathrm{BC}$ constitutes a core inside the particle. The stations in industrial and urban regions are fairly simulated with our model. The stations influenced by dust are more badly reproduced due to the fact that dust is not taken into account in the computation of optical parameters. The simulated single scattering albedo, even in the right range in comparison with the data, could badly reproduce the observations in some particular cases where absorption is 
dominant. This shows the difficulties in simulating the absorbing part of the aerosol optical properties.

Comparisons with other data will also be necessary. Satellite measurements provide a better spatial description and give an information that is similar to an average over one pixel (typically a grid cell) considered. They are therefore more representative of the background aerosols than a ground-based station. Also lidar measurements will give more information about the vertical representation of aerosols and will be explored in future work. To investigate lidars at a continental scale, the EARLINET network has been created (Bösenberg et al., 2001). But the advantages of using such high resolution data from lidar could be fully exploited at a regional scale; the investigation of the LISAIR campaign (Raut and Chazette, 2007a) will be carried out in a future work.

The results of the sensitivity analysis presented in this paper leads to many observations and could be extended, but the details are not our objective in this study. The main points are quoted hereafter. The hypothesis of the mixing state of the $\mathrm{BC}$ component has a non-negligible influence on the single scattering albedo. Then, the advances in modeling the external mixing of aerosols in CTM could be of great importance. The water content parameter increases the uncertainties on SSA as well as on AOT. But the uncertainties in physical parameterizations of actual aerosol models could be more important for the optical properties than the model used for optics itself. The more important uncertainties reside in the chemical composition of the particles, the mass distribution and the number of small particles.

A next step for the model is to improve the modeling of secondary organic component of particles and their hydrophylic or hydrophobic properties (Pun and Seigneur, 2007) to be more accurate on the ALWC. Moreover, the organic species have not been investigated in this paper, but their complex refractive index and the uncertainties on their values could lead to important differences on optical properties. As it is commonly proved that actual models underpredict a great part of the concentration of organic species, the influence could be even larger.

As the repartition of aerosols between fine and coarse particles is crucial for the computation of optical parameters, aerosol models have to be validated in that way for a large set of data. The LISAIR campaign also investigate the chemical characterization of aerosols for two modes (fine and coarse). The ability of the model to reproduce the chemical and granulometric repartition of the aerosols, in that particular urban case, will be assessed in a future work.

The atmospheric optical properties also depend on the number of particles (see the influence of the nucleation process). The number distribution is at the moment not validated because of the lack of observation. Validation of the number distribution simulated by models has then to be investigated. This requires short-range simulations with appropriate models (perhaps Atmospheric Computational Fluid Dynamics codes).

Acknowledgements. The authors thank the AERONET network for providing freely the AOT and SSA observations and the Principal Investigators of each site cited here. We thank also the Mozart and GOCART teams for providing us their results at global scale. The authors are grateful to Vivien Mallet for his advices in ensemble forecasts. One of the author, Marilyne Tombette, is partially funded by the Ile de France region.

Edited by: K. Lehtinen

\section{References}

Baumgardner, D., Raga, G. B., Kok, G., Ogren, J., Rosas, I., Baez, A., and Novakov, T.: On the evolution of aerosol properties at a mountain site above Mexico City, J. Geophys. Res., 105, 22243 $22253,2000$.

Bergin, M. H., Cass, G. R., Xu, J., Fang, C., Zeng, L. M., Yu, T., Salmon, L. G., Kiang, C. S., Tang, X. Y., Zhang, Y. H., and Chameides, W. L.: Aerosol radiative, physical, and chemical properties in Beijing during June 1999, J. Geophys. Res., 106, 17 969-17 980, 2001.

Bösenberg, J., Ansmann, A., Aldasano, J. M. B., Balis, D., Bockmann, C., Calpini, B., Chaikovski, A., Flamant, P., Hagard, A., Mitev, V., Papayannis, A., Pelon, J., Resendes, D., Schneider, J., Spinelli, N., Trickl, T., Vaughan, G., Visconti, G., and Wiegner, M.: EARLINET: A European Aerosol Research Lidar Network, Laser Remote Sensing of the Atmosphere, Selected Papers of the 20th International Laser Radar Conference, Vichy, France, edited by: Dabas, A., Loth, C., and Pelon, J., 155-158, 2001.

Boucher, O. and Anderson, T. H.: General circulation model assessment of the sensitivity of direct climate forcing by anthropogenic sulfate aerosols to aerosol size and chemistry, J. Geophys. Res., 100, 26 117-26 134, 1995.

Boutahar, J., Lacour, S., Mallet, V., Quelo, D., Roustan, Y., and Sportisse, B.: Development and validation of a fully modular platform for numerical modelling of air pollution: POLAIR, Int J. Environ. Pollut., 22(1/2), 17-28, 2004.

Brindley, H. E. and Ignatov, A.: Retrieval of mineral aerosol optical depth and size information from Meteosat Second Generation SEVIRI solar reflectance bands, Remote Sens. Environ., 102, 344-363, 2006.

Chazette, P. and Liousse, C.: A case study of optical and chemical ground apportionment for urban aerosols in Thessaloniki, Atmos. Environ., 35, 2497-2506, 2000.

Chazette, P., Randriamiarisoa, H., Sanak, J., Couvert, P., and Flamant, C.: Optical properties of urban aerosol from airborne and ground-based in situ measurements performed during the ESQUIF program, J. Geophys. Res., 110, D02206, doi:10.1029/2004JD004 810, 2005.

Chin, M., Rood, R., Lin, S.-J., Muller, J. F., and Thompson, A. M.: Atmospheric sulfur cycle in the global model GOCART: Model description and global properties, J. Geophys. Res., 105, 24671 24 688, 2000.

Chin, M., Ginoux, P., Kinne, S., Torres, O., Holben, B. N., Duncan, B. N., Martin, R. V., Logan, J. A., Higurashi, A., and Nakajima, T.: Tropospheric aerosol optical thickness from the GOCART 
model and comparisons with satellite and sun photometer measurements, J. Atmos. Sci., 59, 461-483, 2002.

Chung, C. E., Ramanathan, V., Kim, D., and Podgorny, I. A.: Global anthropogenic aerosol direct forcing derived from satellite and ground-based observations, J. Geophys. Res., 110, D24207, doi:10.1029/2005JD006 356, 2005.

Chung, S. and Seinfeld, J.: Global distribution and forcing of carbonaceous aerosols, J. Geophys. Res., 107(D19), 4407, doi:10.1029/2001JD001 397, 2002.

CMAQ: Science Algorithms of the EPA Models-3 Community Multiscale Air Quality (CMAQ) modeling system, Tech. rep., U.S. Environmental Protection Agency, ePA/600/R-99/030, 1999.

Debry, E. and Sportisse, B.: Reduction of the condensation/evaporation dynamics for atmospheric aerosols: theoretical and numerical investigation of hybrid methods, J. Aerosol Sci., 37, 950-966, 2006.

Debry, E., Fahey, K., Sartelet, K., Sportisse, B., and Tombette, M.: Technical note: A new SIze REsolved Aerosol Model, Atmos. Chem. Phys., 7, 1537-1547, 2007, http://www.atmos-chem-phys.net/7/1537/2007/.

Deuzé, J. L., Bréon, F. M., Devaux, C., Goloub, P., Herman, M., Lafrance, B., Maignan, F., Marchand, A. Nadal, F., Perry, G., and Tanré, D.: Remote sensing of aerosols over land surfaces from POLDER-ADEOS-1 polarized measurements, J. Geophys. Res., 106, 4913-4926, 2001.

Dickerson, R. R., Kondragunta, S., Stenchikov, G., Civerolo, K. L., Doddridge, B. G., and Holben, N.: The Impact of Aerosols on Solar Ultraviolet Radiation and Photochemical Smog, Science, 278, 827-830, 1997.

Dubovik, O., Smirnov, A., Holben, B. N., King, M. D., Kaufman, Y. J., Eck, T. F., and Slutsker, I.: Accuracy assessments of aerosol optical properties retrieved from AERONET Sun and sky-radiance measurements, J. Geophys. Res., 105, 9791-9806, 2000.

Fahey, K. M. and Pandis, S. N.: Optimizing model performance: variable size resolution in cloud chemistry modeling, Atmos. Environ., 35, 4471-4478, 2001.

Forster, P., Ramaswamy, V., Artaxo, P., Berntsen, T., Betts, R., Fahey, D. W., Haywood, J., Lean, J., Lowe, D. C., Myhre, G., Nganga, J., Prinn, R., Raga, G., Schulz, M., and van Dorland, R.: Changes in atmospheric constituents and in radiative forcing, in : Climate Change 2007: The physical science basis. Contribution of working group I to the fourth assessment report of the intergovernmental panel on climate change, edited by: Solomon, S., Qin, D., Manning, M., Chen, Z., Marquis, M., Averyt, K. B., Tignor, M., and Miller, H. L., 2007.

Gerber, H.: Relative-humidity parameterization of the Navy Aerosol Model, Technical report 8956, Natl. Res. Lab. Washington D.C., 1985.

Ginoux, P., Horrowitz, L. W., Ramaswamy, V., Geogdzhayev, I. V., Holben, B. N., Stenchikov, G., and Tie, X.: Evaluation of aerosol distribution and optical depth in the Geophysical Fluid Dynamics Laboratory coupled model CM2.1 for present climate, J. Geophys. Res., 111, D22210, doi:10.1029/2005JD006 707, 2006.

Hamonou, E., Chazette, P., Balis, D., Dulac, F., Schneider, X., Galani, E., Ancellet, G., and Papayannis, A.: Characterization of the vertical structure of Saharan dust export to the Mediterranean basin, J. Geophys. Res., 104, 22 257-22 270, 1999.
Hänel, G.: The properties of atmospheric aerosols as function of the relative humidity at thermodynamic equilibrium with the surrounding moist air, Adv. Geophys., 19, 73-188, 1976.

Hess, M., Koepke, P., and Schult, I.: Optical properties of aerosols and clouds: the software package OPAC, Bull. Amer. Meteor. Soc., 79, 831-844, 1998.

Hodzic, A., Chepfer, H., Vautard, R., Chazette, P., Beekmann, M., Bessagnet, B., Chatenet, B., Cuesta, J., Drobinski, P., Haefflin, M., and Morille, Y. a.: Comparison of aerosol chemistry transport model simulations with lidar and Sun photometer observations at a site near Paris, J. Geophys. Res., 109, D23201, doi:10.1029/2004JD004 735, 2004.

Hodzic, A., Vautard, R., Chepfer, H., Goloub, P., Menut, L., Chazette, P., Deuzé, J.-L., Apituley, A., and Couvert, P.: Evolution of aerosol optical thickness over Europe during the August 2003 heat wave as seen from CHIMERE model simulations and POLDER data, Atmos. Chem. Phys., 6, 1853-1864, 2006, http://www.atmos-chem-phys.net/6/1853/2006/.

Hodzic, A., Madronich, S., Bohn, B., Massie, S., Menut, L., and Wiedinmyer, C.: Wildfire particulate matter in Europe during summer 2003: Meso-scale modeling of smoke emissions, transport and radiative effects, Atmos. Chem. Phys. Discuss., 7, 47814855, 2007, http://www.atmos-chem-phys-discuss.net/7/4781/2007/.

Holben, B. N., Tanré, D., Smirnov, A., Eck, T. K., Slutsker, I., Abuhassan, N., Newcomb, W. W., Schafer, J. S., Chatenet, B., Lavenu, F., Kaufman, Y. J., Castle, J. V., Setzer, A., Markham, B., Clark, D., Frouin, R., Halthore, R., Karneli, A., O’Neil, N. T., Pietras, C., Pinker, R. T., Vass, K., and Zibordi, G.: An emerging ground-based aerosol climatology: Aerosol optical depth from AERONET, J. Geophys. Res., 106, 12 067-12 097, 2001.

Houghton, J., Ding, Y., Griggs, D., Noguer, M., van der Linden, P., Dai, X., Maskell, K., Johnson, C., Meira Filho, L., Bruce, J., Lee, H., Callander, B., Haites, E., Harris, N., and Maskell, K.: Climate change 2001, The scientific basis, an evaluation of the IPCC, Cambridge University Press, New York, 2001.

Jacob, D.: Heterogeneous chemistry and tropospheric ozone, Atmos. Environ., 34, 2131-2159, 2000.

Jacobson, M. Z.: A physically-based treatment of elemental carbon optics: Implications for global direct forcing of aerosols, Geophys. Res. Lett., 27, 217-220, 2000.

Jeuken, A., Veefkind, J. P., Dentener, F., Metzger, S., and Robles Gonzáles, C.: Simulation of the optical depth over Europe for August 1997 and a comparison with observation, J. Geophys. Res., 106, 28 295-28 311, 2001.

Kaskaoutis, D. G., Kambezidis, H. D., Hatzianastassiou, N., Kosmopoulos, P. G., and Badarinath, K. V. S.: Aerosol climatology: on the discrimination of aerosol types over four AERONET sites, Atmos. Chem. Phys. Discuss., 7, 6357-6411, 2007, http://www.atmos-chem-phys-discuss.net/7/6357/2007/.

Katrinak, K. A., Rez, P., Perkes, P. R., and Buseck, P. R.: Fractal geometry of carbonaceous agregates from an urban aerosol, Environ. Sci. Technol., 27, 539-547, 1993.

Kaufman, Y. J., Tanré, D., Remer, L. A., Vermote, E. F., Chu, A., and Holben, B. N.: Operational remote sensing of tropospheric aerosol over land from EOS moderate resolution imaging spectroradiometer, J. Geophys. Res., 102, 17 051-17 068, 1997.

Kinne, S., Schultz, M., Textor, C., Guibert, S., Balkanski, Y., Bauer, S. E., Berntsen, T., Berglen, T. F., Boucher, O., Chin, M., Collins, 
W., Dentener, F., Diehl, T., Easter, R., Feichetr, J., Fillmore, D., Ghan, S., Ginoux, P., Gong, S., Grini, A., Hendricks, J., Herzog, M., Horowitz, L., Isaken, I., Iversen, T., Kirkevag, A., Kloster, S., Koch, D. an Kristjansson, J. E., Krol, M., Lauer, A., Lamarque, J. F., Lesins, G., Liu, X., Lohmann, U., Montanaro, V., Myhre, G., Penner, J. E., Pitari, G., Reddy, S., Seland, O., Stier, P., Takemura, T., and Tie, X. a.: An AeroCom initial assessment - Optical properties in aerosol component modules of global models, Atmos. Chem. Phys., 6, 1815-1834, 2006, http://www.atmos-chem-phys.net/6/1815/2006/.

Koh, G.: Effective dieclectric constant of a medium with sperical inclusions, IEEE T. Geosci. Remote, 30, 184-186, 1992.

Léon, J., Chazette, P., Pelon, J., Dulac, F., and Randriamarisoa, H.: Aerosol direct radiative impact over the INDOEX area based on passive and active remote sensing, J. Geophys. Res., 107(D19), 8006, doi:10.1029/2000JD000 116, 2002.

Lesins, G., Chylek, P., and Lohmann, U.: A study of internal and external mixing scenarios and its effect on aerosol optical properties and direct radiative forcing, J. Geophys. Res., 107(D10), 4094, doi:10.1029/2001JD000973, 2002.

Lohmann, U. and Feichter, J.: Global indirect aerosol effects: a review, Atmos. Chem. Phys., 5, 715-737, 2005, http://www.atmos-chem-phys.net/5/715/2005/.

Louis, J.-F.: A parametric model of vertical eddy fluxes in the atmosphere, Bound.-Lay. Meteorol., 17, 187-202, 1979.

Mallet, M., Roger, J., Despiau, S., Dubovik, O., and Putaud, J.: Microphysical and optical properties of aerosol particles in urban zone during ESCOMPTE, Atmos. Res., 69, 73-97, 2003.

Mallet, V. and Sportisse, B.: Uncertainty in a chemistry-transport model due to physical parametrizations and numerical approximations: An ensemble approach applied to ozone modeling, J. Geophys. Res., 111, D01302, doi:10.1029/2005JD006 149, 2006.

Mallet, V., Quélo, D., Sportisse, B., Ahmed de Biasi, M., Debry, É., Korsakissok, I., Wu, L., Roustan, Y., Sartelet, K., Tombette, M., and Foudhil, H.: Technical Note: The air quality modeling system Polyphemus, Atmos. Chem. Phys., 7, 5479-5487, 2007, http://www.atmos-chem-phys.net/7/5479/2007/.

Maxwell-Garnett, J. C.: Colours in Metal Glasses and in Metallic Films, Philos. T. Roy. Soc. A, 203, 385-420, 1904.

Mie, G.: Beiträge zur Optik trüber Medien, speziell kolloidaler Metallösungen, Ann. Phys.-Leipzig, 330, 377-445, 1908.

Monahan, E. C., Spiel, D. E., and Davidson, K. L.:: A model of marine aerosol generation via whitecaps and wave disruption, in: Oceanic whitecaps and their role in air-sea exchange, edited by: Monahan, E. C., Spiel, D. E., Davidson, K. L., and Reidel, D., 167-174, 1986.

Moulin, C., Lambert, C., Dulac, F., and Dayan, U.: Control of Atmospheric Export of dust from North Africa by the North Atlantic Oscillation, Nature, 387, 691-694, 1997.

Nenes, A., Pandis, S., and Pilinis, C.: ISORROPIA: A new thermodynamic equilibrium model for multiphase multicomponent inorganic aerosols, Aquat. Geochem., 4, 123-152, 1998.

Penner, J. E., Chang, S. Y., Chin, M., Chuang, C. C., Feichter, J., Feng, Y., Geogdzhayev, I. V., Ginoux, P., Herzog, M., Higurashi, A., Koch, D., Land, C., Lohmann, U., Mishchenko, M., Nakajima, T., Pitari, G., Soden, B., Tegen, I., and Stowe, L.: A comparison of model- and satellite-derived Aerosol Optical Depth and Reflectivity, J. Atmos. Sci., 59, 441-460, 2002.
Pilinis, C., Capaldo, K., Nenes, A., and Pandis, S.: MADM - a new Multi-component Aerosol Dynamic Model, Aerosol Sci. Tech., 32, 482-502, 2000.

Pun, B. K. and Seigneur, C.: Investigative modeling of new pathways for secondary organic aerosol formation, Atmos. Chem. Phys., 7, 2199-2216, 2007,

http://www.atmos-chem-phys.net/7/2199/2007/.

Putaud, J.-P., Raes, F., Dingenen, R. V., Brüggemann, E., Facchini, M. C., Decesari, S., Fuzzi, S., Gehrig, R., Hüglin, C., Laj, P., Lorbeer, G., Maenhaut, W., Mihalopoulos, N., Müller, K., Querol, X., S. Rodriguez andi, J. S., Spindler, G., ten Brink, H., rseth, K. T., and Wiedensohler, A.: A European aerosol phenomenology - 2: Chemical characteristics of particulate matter at kerbside, urban, rural and background sites in Europe, Atmos. Environ., 38, 2579-2595, 2004.

Ramanathan, V., Crutzen, P. J., Lelieved, J., Mitra, A. P., Althausen, D., Anderson, J., Andreae, M. O., Cantrell, W., Cass, G. R., Chung, C. E., Clarke, A. D., Coakley, J. A., Collins, W. D., Conant, W. C., Dulac, F., Heintzenberg, J., Heymsfield, A. J., Holben, S., Howell, S., Hudson, J., Jayaraman, A., Kiehl, J. T., Krishnamurti, T. N., Lubin, D., McFarquhar, G., Novakov, T., Ogren, J. A., Podgorny, I. A., Prather, K., Priestley, K., Prospero, J. M., Quinn, P. K., Rajeev, K., Rash, P., Rupert, S., Sadourny, R., Satheesh, S. K., Sham, G. E., Sheridan, P., and Valero, P. J.: Indian Ocean Experiment: An integrated analysis of the climate forcing and effects of the great Indo-Asian haze, J. Geophys. Res., 106, 28 371-28 398, 2001.

Randriamiarisoa, H., Chazette, P., and Mégie, G.: The columnar retrieved single scattering albedo from $\mathrm{NO} 2$ photolysis rate, Tellus B, 56, 118-127, 2004.

Randriamiarisoa, H., Chazette, P., Couvert, P., Sanak, J., and Mégie, G.: Relative humidity impact on aerosol parameters in a Paris suburban area, Atmos. Chem. Phys., 6, 1389-1407, 2006, http://www.atmos-chem-phys.net/6/1389/2006/.

Raut, J.-C. and Chazette, P.: Retrieval of aerosol complex refractive index from a synergy between lidar, sunphotometer and in situ measurements during LISAIR campaign, Atmos. Chem. Phys. Discuss., 7, 1017-1065, 2007a,

http://www.atmos-chem-phys-discuss.net/7/1017/2007/.

Raut, J.-C. and Chazette, P.: Vertical profiles of urban aerosol complex refractive index in the frame of ESQUIF airborne measurements, Atmos. Chem. Phys. Discuss., 7, 10 799-10 835, 2007b, http://www.atmos-chem-phys-discuss.net/7/10799/2007/.

Robles González, C., Schaap, M., de Leeuw, G., Builtjes, P. J. H., and Van Loon, M.: Spatial variation of aerosol properties over Europe derived from satellite observations and comparison with model calculations, Atmos. Chem. Phys., 3, 521-533, 2003, http://www.atmos-chem-phys.net/3/521/2003/.

Sartelet, K. N., Debry, E., Fahey, K. M., Roustan, Y., Tombette, M., and Sportisse, B.: Simulation of aerosols and gas-phase species over Europe with the Polyphemus system. Part I: model-to-data comparison for 2001, Atmos. Environ., 29, 6116-6131, 2007.

Schaap, M., Van Loon, M., ten Brink, H. M., Dentener, F. J., and Builtjes, P. J. H.: Secondary inorganic aerosol simulations for Europe with special attention to nitrate, Atmos. Chem. Phys., 4, 857-874, 2004, http://www.atmos-chem-phys.net/4/857/2004/. 
Schell, B., Ackermann, I. J., and Haas, H.: Modeling the formation of secondary organic aerosol within a comprehensive air quality model system, J. Geophys. Res., 106, 28 275-28 293, 2001.

Seinfeld, J. H. and Pandis, S. N.: Atmospheric chemistry and physics, Wiley-Interscience, 1998.

Smith, M. H. and Harrison, N. M.: The sea spray generation function, J. Atmos. Sci., 29, S189-S190, 1998.

Sportisse, B., Debry, E., Fahey, K., Roustan, Y., Sartelet, K., and Tombette, M.: PAM project (Multiphase Air Pollution): description of the aerosol models SIREAM and MAM, Tech. Rep. 200608, CEREA, http://www.enpc.fr/cerea/polyphemus, 2006.

Stockwell, W., Kirchner, F., and Kuhn, M.: A new Mechanism for regional chemistry modeling, J. Geophys. Res., 102, $25847-$ $25879,1997$.

Strader, R., Gurciullo, C., Pandis, S., Kumar, N., and Lurmann, F.: Development of a gas-phase chemistry, secondary organic aerosol and aquesous-phase chemistry modules for PM modelling, Technical report, STI, 1998.
Tombette, M. and Sportisse, B.: Aerosol modeling at a regional scale: Model-to-data comparison and sensitivity analysis over Greater Paris, Atmos. Environ., 41, 6941-6950, 2007.

Troen, I. B. and Mahrt, L.: A simple model of the atmospheric boundary layer; sensitivity to surface evaporation, Bound.-Lay. Meteorol., 37, 129-148, 1986.

Warneck, P.: Chemistry of the natural atmosphere, Academic Press, New York, 1988.

Wiscombe, W. J.: Improved Mie scattering algorithms, Appl. Optics, 19, 1505-1509, 1980.

Yu, H., Kaufman, Y. J., Chin, M., Feingold, G., Remer, L. A., Anderson, T. L., Balkanski, Y., Belloin, N., Boucher, O., Christopher, S., DeCola, P., Kahn, R., Koch, D., Loeb, N., Reddy, M. S., Schultz, M., Takemura, T., and Zhou, M.: A review of measurement-based assessments of the aerosol direct radiative effect and forcing, Atmos. Chem. Phys., 6, 613-666, 2006, http://www.atmos-chem-phys.net/6/613/2006/. 